\title{
COSTS OF WAR
}

\section{Pentagon Fuel Use, Climate Change, and the Costs of War}

\author{
Neta C. Crawford ${ }^{1}$ \\ Boston University
}

\section{Updated and Revised, 13 November $2019^{2}$}

\section{Summary}

If climate change is a "threat multiplier," as some national security experts and members of the military argue, how does the US military reduce climate change caused threats? Or does war and the preparation for it increase those risks?

In its quest for security, the United States spends more on the military than any other country in the world, certainly much more than the combined military spending of its major rivals, Russia and China. Authorized at over $\$ 700$ billion in Fiscal Year 2019, and with over $\$ 700$ billion requested for FY2020, the Department of Defense (DOD) budget comprises more than half of all federal discretionary spending each year. With an armed force of more than two million people, 11 nuclear aircraft carriers, and the world's most advanced military aircraft, the US is more than capable of projecting power anywhere in the globe, and with "Space Command," into outer space. Further, the US has been continuously at war since late 2001, with the US military and State Department currently engaged in more than 80 countries in counterterror operations. ${ }^{3}$

All this capacity for and use of military force requires a great deal of energy, most of it in the form of fossil fuel. As General David Petraeus said in 2011, "Energy is the lifeblood of our warfighting capabilities." 4 Although the Pentagon has, in recent years, increasingly

\footnotetext{
${ }^{1}$ Neta C. Crawford is Professor and Chair of Political Science at Boston University, and Co-Director of the Costs of War project at Brown and Boston Universities. Crawford thanks Matthew Evangelista, Anna Henchman, Catherine Lutz, Heidi Peltier, Nathan Phillips, Stephanie Savell, Adam Sweeting, Alexander Thompson and David Vine for their critical comments and helpful suggestions. Crawford also benefited from feedback at Ohio State University in April 2019 and Brown University in September 2019.

2 The previous study, released in June 2019, included calculations of emissions from Fiscal Years (FY) 1975 to 2017. This updated and revised version adds the DOD FY2018 fuel consumption and emissions data released by the Department of Energy and a discussion of trends in DOD fuel use and emissions at DOD facilities. ${ }^{3}$ Crawford estimates that the budgetary costs of the post-9/11 wars, including Homeland Security and future obligations to care for the veterans of these wars, are more than $\$ 6$ trillion dollars. Neta C. Crawford, "United States Budgetary Costs and Obligations of Post-9/11 Wars through FY2020: \$6.4 Trillion," November 2019. ${ }^{4}$ General David Petraeus, quoted in Department of Energy, "Energy for the Warfighter: The Department of Defense Operational Energy Strategy," 14 June 2011, https://www.energy.gov/articles/energy-war-fighterdepartment-defense-operational-energy-strategy.
} 
emphasized energy security-energy resilience and conservation-it is still a significant consumer of fossil fuel energy. Indeed, the DOD is the world's largest institutional user of petroleum and correspondingly, the single largest institutional producer of greenhouse gases (GHG) in the world. 5 From FY1975 to FY2018, total DOD greenhouse gas emissions were more than 3,685 Million Metric Tons of CO2 equivalent. While only a portion of US total emissions, US military emissions are, in any one year, larger than the emissions of many countries. In 2017, for example, the Pentagon's total greenhouse gas emissions (installations and operations) were greater than the greenhouse gas emissions of entire industrialized countries, such as Sweden, Denmark and Portugal and also greater than all CO2 emissions from US production of iron and steel.

This paper estimates US military emissions and military fuel usage for the US post-9/11 wars. The best estimate of total US military greenhouse gas emissions (including installations and operations) from 2001 when the wars began with the US invasion of Afghanistan, through FY2018, is 1,267 million metric tons of greenhouse gases (measured in CO2equivalent, or CO2e). The Overseas Contingency Operations (war-related) greenhouse gas emissions portion of those emissions-including for the major war zones of Afghanistan, Pakistan, Iraq and Syria - is estimated to be more than 440 Million Metric Tons of CO2e for the period of FY2001-2018 (summarized in Table 2). ${ }^{6}$

The US military is preparing for threats of attack from human adversaries including terrorists. The threats of terrorism and Russian, Iranian, Chinese or Korean aggression are all real, but terrorists and these countries are not certain to attack the US. Arms control and diplomacy can deescalate tensions and reduce threats. Economic sanctions can also diminish the capacity of states and non-state actors to threaten the security interests of the US and its allies.

Global warming is the most certain and immediate of any of the threats that the US faces in the next several decades. In fact, global warming has begun: drought, fire, flooding, and temperature extremes will lead to displacement and death. The effects of climate change, including extremely powerful storms, famine, and diminished access to fresh water, will likely make regions of the world unstable-feeding political tensions and fueling mass migrations and refugee crises. In response, the military has added the national security implications of climate change to its long list of national security concerns.

Unlike some elements of the present US administration, which is in various modes of climate denial, the US military and intelligence community act as if the negative security

\footnotetext{
5 These emissions are a result not only of war, but also of on-going non-war operations, exercises, wargames, and the maintenance of military installations. For a discussion of the concept of greenhouse gas equivalencies, see Appendix 1. US Environmental Protection Agency, Greenhouse Gases Equivalencies Calculator, https://www.epa.gov/energy/greenhouse-gases-equivalencies-calculator-calculations-andreferences.

${ }^{6}$ See Appendix 1. This is a conservative estimate. Not including biogenic sources or reductions from renewable energy use; the latter were less than 1 percent of emissions. In the most recent year for which statistics are available, total greenhouse gas emissions by the DOD for FY2018 were about 56 million metric tons of $\mathrm{CO} 2$ equivalent, a reduction from the previous year.
} 
consequences of a warming planet are inevitable. The DOD has studied the problem for decades and begun to adapt its plans, operations and installations to deal with climate change.

The US military has an opportunity to reduce the risks associated with climate change-and the security threats associated with climate change-by reducing their role in creating greenhouse gas emissions. While some sea level rise and mass extinction will certainly occur - these changes have already begun - the most dire consequences of climate change and the associated threats and consequences to national security are not already baked into the system. ${ }^{7}$ There is time to act to reduce greenhouse gas emissions and it is urgent to do so. If the US military were to significantly decrease its greenhouse gas emissions, it would make the dire climate change caused national security threats the US military fears and predicts less likely to occur.

Absent any change in US military fuel use policy, the fuel consumption of the US military will necessarily continue to generate high levels of greenhouse gases. These greenhouse gases, combined with other US emissions, will help guarantee the nightmare scenarios that the military predicts and that many climate scientists say are possible.

Yet, the Pentagon does not acknowledge that its own fuel use is a major contributor to climate change. The military uses a great deal of fossil fuel protecting access to Persian Gulf Oil. Because the current trend is that the US and indeed the world economy is becoming less dependent on oil, it may be that the mission of protecting Persian Gulf oil is, in most instances, no longer vital and the US military can reduce its presence in the Persian Gulf. The Pentagon can also reduce US military greenhouse gas emissions in other ways. These alternatives are discussed more in Appendix 2, which suggests specific measures Congress might consider to reduce DOD fossil fuel consumption and simultaneously reduce risk of climate change caused conflict.

Reductions in military fossil fuel use would be beneficial in four ways. First, the US would reduce its overall greenhouse gas emissions. This would thereby mitigate climate change and its associated threats to national security. Second, reducing fossil fuel consumption would have important political and security benefits, including reducing the dependence of troops in the field on oil, which the military acknowledges makes them vulnerable to enemy attacks. If the US military were to significantly decrease its dependence on oil, the US could reduce the political and fuel resources it uses to defend access to oil, particularly in the Persian Gulf, where it concentrates these efforts. Third, by decreasing US dependence on oil-rich states the US could then reevaluate the size of the US military presence in the Persian Gulf and reevaluate its relationship with Saudi Arabia and other allies in the region. Finally, by spending less money on fuel and operations to provide secure access to petroleum, the US could decrease its military spending and reorient the economy to more economically productive activities.

\footnotetext{
${ }^{7}$ Keeping global warming to less than $1.5^{\circ} \mathrm{C}$ yields a much more livable planet than if the climate warms more than that. Intergovernmental Panel on Climate Change (IPCC), "Global Warming of $1.5^{\circ} \mathrm{C}$," Summary for Policymakers, (Switzerland: IPCC, 2018).
} 
Part I of this paper outlines the scale and pattern of US military fuel use, including the petroleum resources that the US uses to protect access to Persian Gulf oil. Part II estimates greenhouse gas emissions by the US military and the portion of those emissions that are a consequence of the major post-9/11 US wars. The US military has begun greenhouse gas emissions reductions, but there is room for much steeper cuts. For readers interested in further detail, Appendix 1 elaborates on technical issues and summarizes the sources of data and assumptions for the best estimates of greenhouse gas emissions the US has made in war from 2001 to 2018. It also describes the long-term trend in DOD emissions from FY1975-2018 and discusses trends in facilities emissions.

Part III of the paper summarizes the way the US military understands the national security implications of the military's oil dependency and climate change. The Pentagon views climate change as a threat to military installations and operations, as well as to national security when and if climate change leads mass migration, conflict, and war.

\section{US Military Energy Consumption and Fuel}

War and preparation for it are fossil fuel intensive activities. The US military's energy consumption drives total US government energy consumption. The DOD is the single largest consumer of energy in the US, and in fact, the world's single largest institutional consumer of petroleum. Since 2001, the DOD has consistently consumed between 77 and 80 percent of all US government energy consumption. Figure 1 tracks total US Federal government energy consumption and Department of Defense consumption.

Figure 1. DOD and Total US Federal Government Energy Consumption, FY1975-2018, in Trillions of British Thermal Units ${ }^{8}$

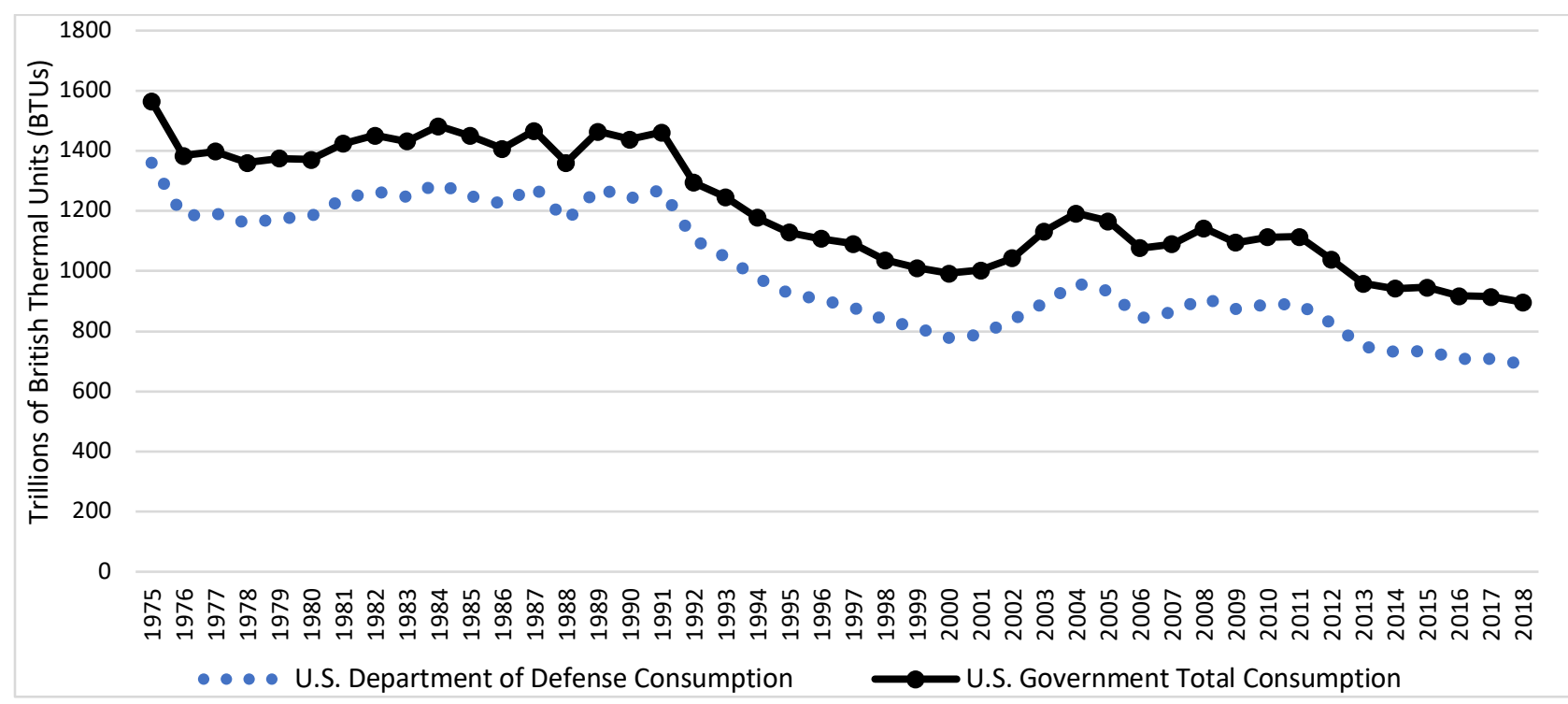

${ }^{8}$ In Trillions of British Thermal Units. Source of data: US Energy Information Administration. https://www.eia.gov/totalenergy/data/monthly/dataunits.php. 
From 1975 until 1990, the total energy consumed by the DOD was essentially steady. There was a spike in US military consumption during the 1991 Gulf War, even as US alliance partners, namely Saudi Arabia, provided much of the fuel used in that war. After the 1991 Gulf War, and with the end of the Cold War, US military energy consumption declined until the 9/11 attacks. In 2001, as a consequence of beginning a major war in Afghanistan, energy consumption by the DOD increased, and in 2005 hit its highest level in a decade.

Since the 2007 Energy Independence and Security Act the US government has gradually decreased its overall energy use. ${ }^{9}$ Only in FY2013 did DOD energy consumption return to the level it was in 2000. The headline from the Energy Information Administration announcing the transition said "Defense Department Energy Use Falls to Lowest Level Since 1975."10 Yet, even as it has realized significant reductions in fossil fuel use, the Pentagon's consumption remains high. Indeed, the military annually consumes more fuel than most countries.

As the next figure illustrates, jet fuel, diesel fuel, and electricity production are the largest elements of DOD, and therefore US government, energy consumption.

Figure 2. Categories of Energy Consumed by the US Government and DOD ${ }^{11}$

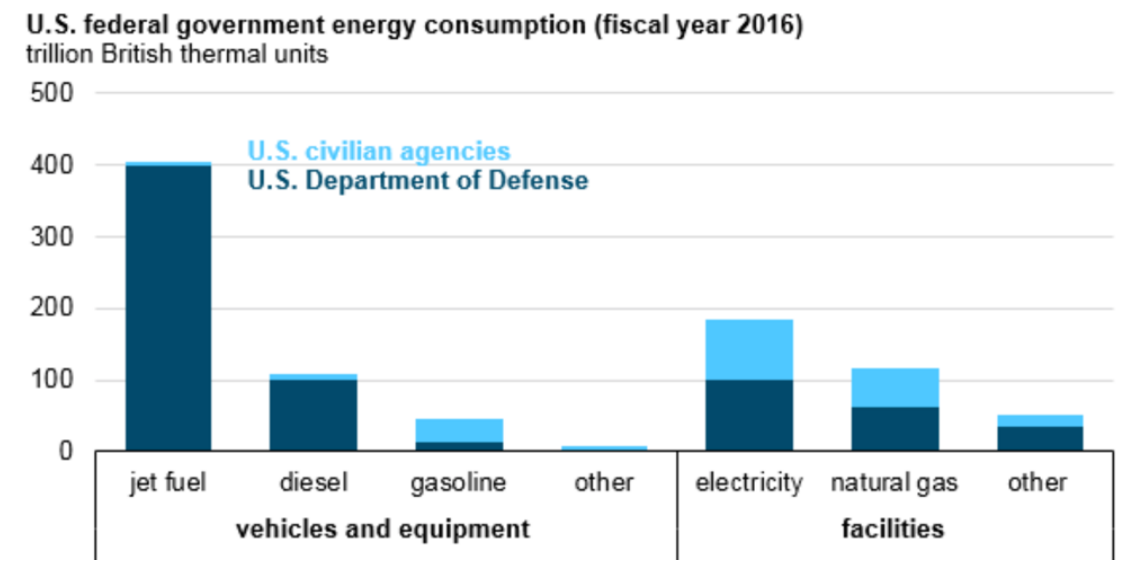

Why does the US military consume so much energy? First, the Pentagon's fighting "tooth" employs equipment that guzzles fuel at an incredible rate. The logistical "tail" and

\footnotetext{
${ }^{9}$ Energy Independence and Security Act of 2007, https://www.govinfo.gov/content/pkg/BILLS$110 \mathrm{hr} 6 \mathrm{enr} / \mathrm{pdf} / \mathrm{BILLS}-110 \mathrm{hr} 6 \mathrm{enr}$.pdf/. See the Department of Defense, "Operational Energy Strategy: Implementation Plan," March 2012, https://www.globalsecurity.org/military/library/policy/dod/operational-energy-strategy implementationplan201203.pdf.

10 US Energy Information System, “Defense Department Energy Use Falls to Lowest Level Since 1975." https://www.eia.gov/todayinenergy/detail.php?id=19871.

11 Source: U.S. Energy Information Administration, "U.S. Federal Government Energy Costs at Lowest Point Since Fiscal Year 2004," 2 October 2017, https://www.eia.gov/todayinenergy/detail.php?id=33152. Overall, gasoline led total US petroleum consumption, followed by diesel fuel and home heating oil, and natural gases (HGLs) of various types.
} 
the installations that support operations are also extremely fuel intensive. Even the military's non-armored vehicles are notoriously inefficient. For instance, the approximately 60,000 HUMVEEs remaining in the US army fleet get between four to eight miles per gallon of diesel fuel. ${ }^{12}$

\section{Installation and Operational Energy Use}

The DOD tracks its energy consumption in two baskets. Energy usage for installations is about 30 percent of Pentagon consumption. Although these military installations in the US and abroad necessarily support operations, the DOD tracks installation energy use separately. ${ }^{13}$ But, as the Pentagon notes, "In many ways, installation energy supports warfighter requirements through secure and resilient sources of commercial electrical energy, and where applicable, energy generation and storage, to support mission loads, power projection platforms, remotely piloted aircraft operations, intelligence support, and cyber operations." 14

The installation tail that supports US operations and power projection capability includes more than 560,000 facilities with over 275,000 buildings at 800 bases located on about 27 million acres of land in the US and across the globe. ${ }^{15}$ In FY2017, the DOD spent $\$ 3.5$ billion to heat, cool, and provide electricity to its facilities, down from the previous year, when it spent $\$ 3.7$ billion. ${ }^{16}$ Each installation, of course, can produce greenhouse gas emissions. The Pentagon building itself, located in Arlington, Virginia emitted 24,620.55 metric tons of CO2e in 2013. ${ }^{17}$

Despite the fact that in May 2018 the Trump administration rescinded the Obama administration's federal energy efficiency goals, the DOD remains committed to reducing

12 Daniel Gouré, “The U.S Army's All-But Forgotten Vehicle Fleet," Real Clear Defense, 22 August 2017, https://www.realcleardefense.com/articles/2017/08/22/the us armys all-

but forgotten vehicle fleet 112116.html. The gas hungry Ford F-150 pickup truck gets 17 miles per gallon in the city; the hungrier Chevrolet Suburban gets 15 miles per gallon in the city.

13 Office of the Assistant Secretary of Defense for Sustainment, "Installation Energy,"

https://www.acq.osd.mil/eie/IE/FEP index.html.

Department of Defense, "2016 Operational Energy Strategy,"

https://www.acq.osd.mil/eie/Downloads/OE/2016\%200E\%20Strategy WEBd.pdf, p. 4.

${ }^{15}$ Each installation consists of one or more sites, which may or may not be located contiguous to the installation. David Vine, "Lists of U.S. Military Bases Abroad, 1776-2019," American University Digital Research Archive, 2019, https://doi.org/10.17606/vfyb-nc07. Also see John Conger, "An Overview of the DOD Installations Enterprise," Heritage Foundation, 4 October 2019, https://www.heritage.org/militarystrength/topical-essays/overview-the-dod-installations-enterprise.

${ }_{16}$ Statement of Honorable Lucian Niemeyer, Assistant Secretary of Defense, Energy, Installations and Environment, before the Senate Committee on Appropriations, Subcommittee on Military Construction, Veterans Affairs, and Related Agencies," 26 April 2018, p. 13.

https://www.acq.osd.mil/eie/Downloads/Testimony/FY19\%20EI\&E\%20Posture\%20Statement\%20\%20SAC-M.pdf; See Office of the Assistant Secretary of Defense for Energy, Installations, and Environment, "Department of Defense Annual Energy Management and Resilience (AEMR) Report, Fiscal Year 2016, (July 2017) p. 15. https://www.acq.osd.mil/eie/Downloads/IE/FY\%202016\%20AEMR.pdf.

${ }^{17}$ See the EPA, https://www.epa.gov/ghgreporting/ghg-reporting-program-data-sets. 
its energy consumption for pragmatic reasons. ${ }^{18}$ The Pentagon and each service branch have multiple projects underway to reduce installation energy use and the overall trend in installation consumption over the last ten years has been downward. Efforts to decrease energy consumption at installations include gradually replacing some non-tactical fleet vehicles with hybrid, plug in hybrid and alternative fuel vehicles, reducing engine idling, developing solar installations at some forts and bases, and concluding power purchase agreements for wind and solar energy. ${ }^{19}$ These efforts have borne fruit as discussed in Appendix 1, but the US military has room for more reductions.

Figure 3 below illustrates the distribution of energy consumption at installations by the service branches and the defense agencies. While the army is the most energy intensive at its installations, energy consumption at installations is relatively equally shared by the service branches.

Figure 3. DOD Installation Energy Consumption, in BTUs, by Service ${ }^{20}$

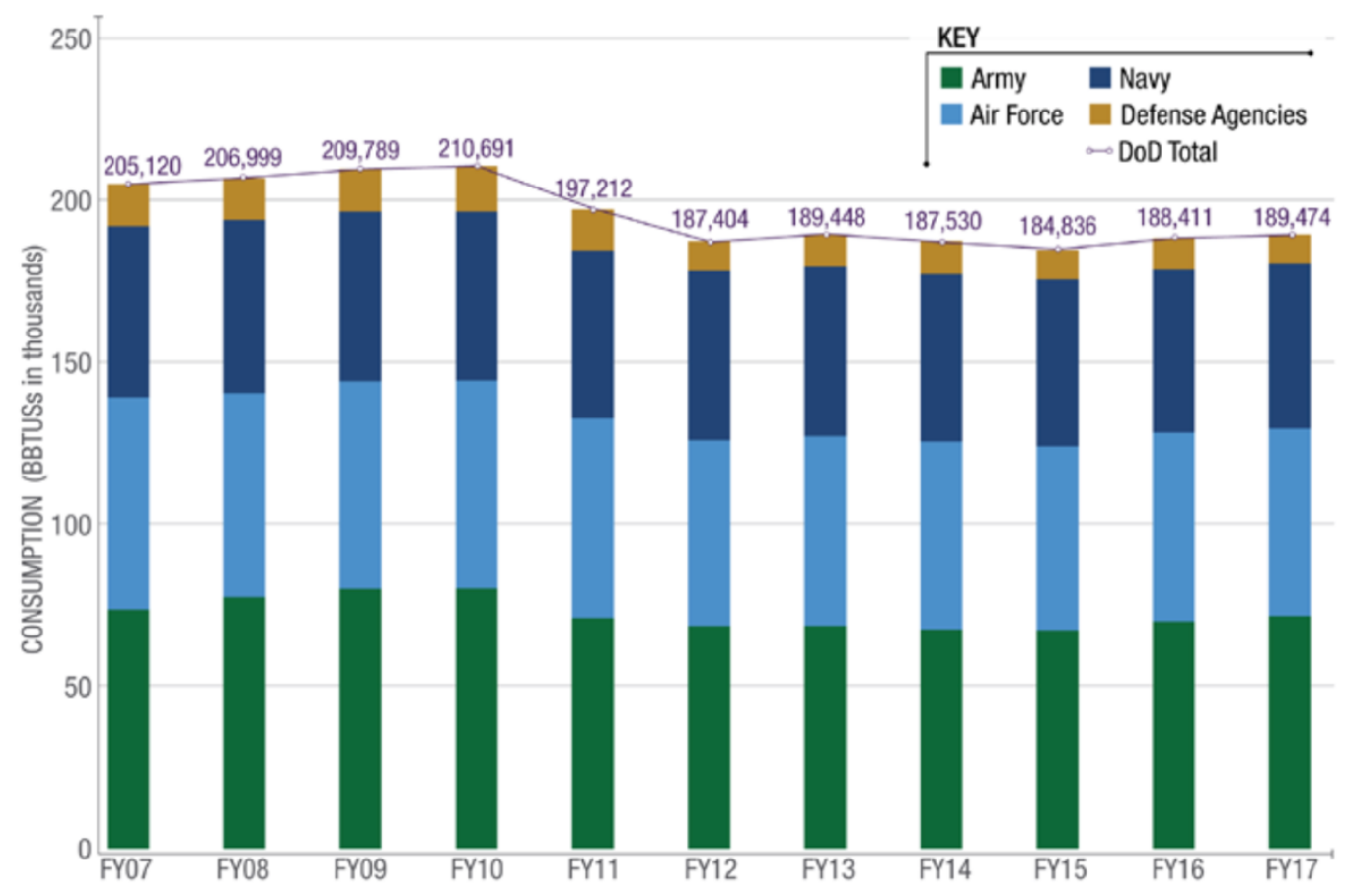

The profile of fossil fuel energy consumption looks different when we consider "operational" energy. Operational energy use, defined as the energy "required for training, moving, and sustaining military forces and weapons platforms" accounts for 70 percent of

\footnotetext{
18 Executive Order 13693 of 19 March 2015 "Planning for Federal Sustainability in the Next Decade" was revoked by President Trump with Executive Order 13834 on 17 May 2018. See

https://www.fedcenter.gov/programs/eo13834/and https://www.fedcenter.gov/programs/eo13693/.

19 The Department of Defense Energy Performance Master Plan was developed in FY2011.

${ }^{20}$ Source: "Figure 4.1: FY2017 Installation Energy (Goal Subject) Consumption by Military Service," from the Office of the Assistant Secretary of Defense for Energy, Installations, and Environment, "Department of Defense Annual Energy Management and Resilience (AEMR) Report, Fiscal Year 2017, (July 2018) p. 12.
} 
DOD energy consumption. ${ }^{21}$ Most operational energy consumed is in the form of "bulk fuel" purchases of jet (JP-8 and JP-5) and diesel fuel..$^{22}$ Operational use varies, of course, depending on what the US military is doing in any particular year-its ongoing and occasional missions. When the US is engaged in war, as one would expect, consumption of jet and diesel fuels increase. Their ratio will depend on the types of operations the military is performing - whether the war or particular phase of the war is land or air intensive.

The figure below shows operational energy use in FY2014, when DOD operational consumption was 87.4 million barrels of petroleum. Jet fuel consumption by all the armed services accounted for more than 70 percent of operational energy use that year. Although all services have aircraft, the Air Force is the largest user of petroleum jet fuel among the armed services. In 2014, the US was largely absent from Iraq, had reduced its forces in Afghanistan, and began its war against ISIS in Syria, which started in August 2014 with air strikes.

Figure 4. Operational Energy Use by Domain and Mission, FY2014 23
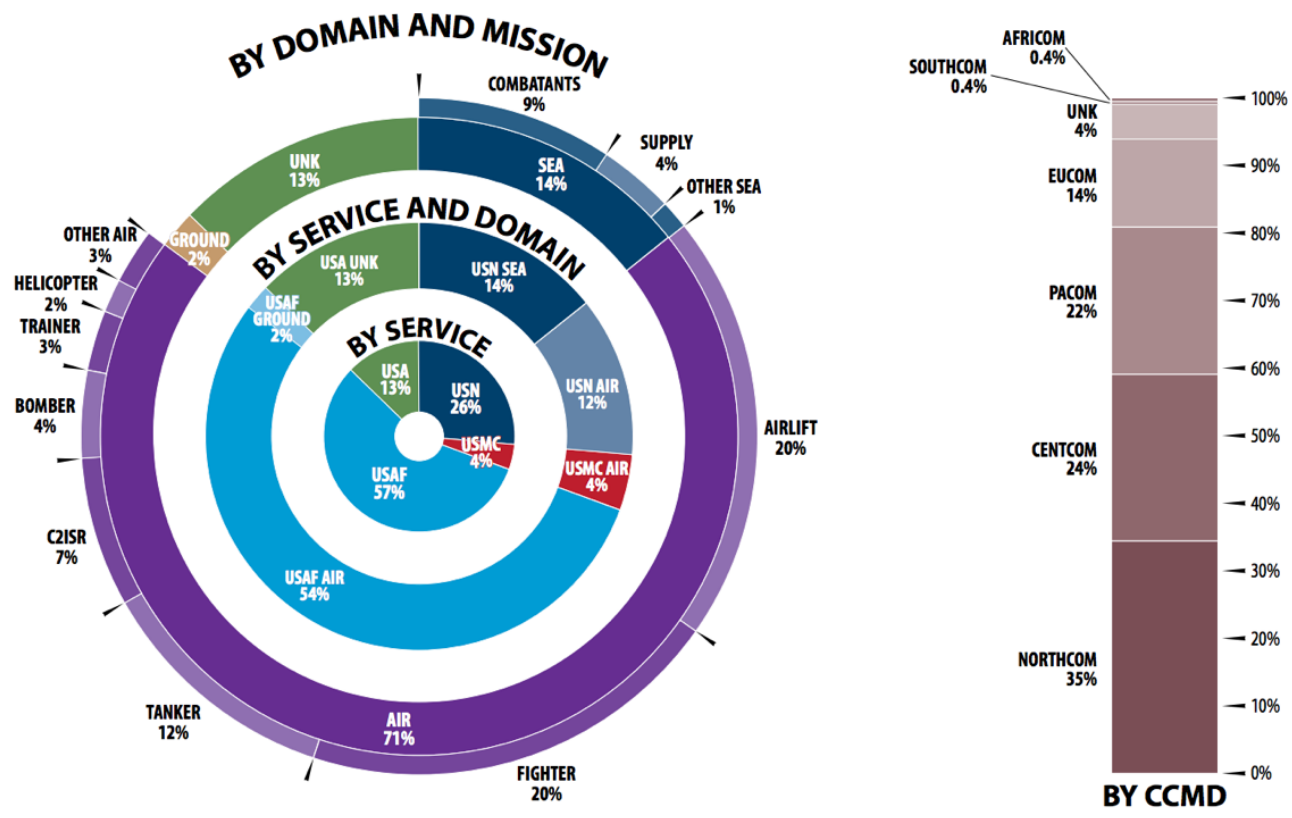

Figure 1: Operational Energy Use, FY 2014

\footnotetext{
${ }^{21}$ Department of Defense, "Operational Energy," https://www.acq.osd.mil/eie/OE/OE index.html.

22 The services may purchase fuel locally and be reimbursed by the Defense Logistics Agency. United States General Accountability Office, "Bulk Fuel: Actions Needed to Improve DOD's Fuel Consumption Budget Data" (GA0-16-664) (September 2016), p. 6. https://www.gao.gov/assets/680/679682.pdf.

23 Department of Defense, "2016 Operational Energy Strategy," https://www.acq.osd.mil/eie/Downloads/OE/2016\%200E\%20Strategy WEBd.pdf, p. 4.
} 
Because operational fuel use is greater than for installation fuel use, the US spends more on it. In FY2017 and again in FY2018 the DOD consumed over 85 million barrels of operational fuel to power ships, aircraft, combat vehicles, and contingency bases at a cost of about $\$ 8.2$ billion in FY2017 and \$9.1 Billion in FY2018. ${ }^{24}$

Operational fuel consumption varies more than installation fuel use. For example, operational fuel consumption in FY2017 and FY2018 was lower than in FY2016. In May 2019, the DOD reported that its anticipated Operational Energy Demand would grow in FY2019 to 88.1 million barrels but would be 87.6 million barrels in FY2020.25

Unsurprisingly then, total US military fuel purchases track US engagement in wars and occupations. All told, from 1998 to 2018 the US purchased about 2.5 billion barrels of petroleum fuel. ${ }^{26}$ Since the 9/11 attacks, the Defense Logistics Agency's average annual fuel purchases been about 122.4 million barrels of all types of fuel. ${ }^{27}$ At the peak of petroleum fuel purchases during this period, from FY2002 through FY2012 (which corresponds to the peak of US fighting in Afghanistan and Iraq war zones), total annual purchases of petroleum products averaged about 134.3 million barrels each year. Purchases declined in recent years as the US has reduced its operations in Iraq and Afghanistan, but slightly increased in FY2018.28 Total petroleum product purchases averaged about 100.6 million barrels a year from FY2013-2018.

\footnotetext{
${ }^{24}$ Office of the Assistant Secretary of Defense for Sustainment. The DOD notes that "Traditionally, the scope of operational energy excludes nuclear energy used for the propulsion of the U.S. Navy's aircraft carriers and submarines, as well as the energy used for military space launch and operations. Operational energy does include the energy needed to operate the carrier's embarked aircraft and helicopters." Department of Defense, "Operational Energy," [emphasis in the original] https://www.acq.osd.mil/eie/OE/OE index.html. The US Navy uses more than 180 nuclear reactors to power over 140 submarines and surface ships including all 11 US aircraft carriers and 70 submarines. See Department of the Navy, "United States Naval Nuclear Propulsion Program," September 2017.

https://www.energy.gov/sites/prod/files/migrated/nnsa/2018/01/f46/united_states_naval_nuclear_propul sion_program_operating_naval_nuclear_propulsion_plants_and_shipping_rail_naval_spent_fuel_safely_for_over sixty years.pdf.

25 In FY2016 the DOD consumed about 86 million barrels of fuel for operational purposes. Office of Undersecretary of Defense for Acquisition, Technology and Logistics, "Fiscal Year 2016 Operational Energy Annual Report," https://www.acq.osd.mil/eie/Downloads/OE/FY16\%200E\%20Annual\%20Report.pdf. See the Office of the Assistant Secretary of Defense for Acquisition and Sustainment, "Fiscal Year 2018 Operational Energy Annual Report," May 2019, p. 22,

https://www.acq.osd.mil/eie/Downloads/OE/FY18\%200E\%20Annual\%20Report.pdf.

26 The 1999 spike in jet fuel purchases corresponds with the 78-day NATO air war in Kosovo to which the US contributed more than 500 aircraft. For statistics on the US role, see https://www.afhistory.af.mil/FAQs/Fact-Sheets/Article/458957/operation-allied-force/.

${ }^{27}$ FY2002 through FY2018.

${ }^{28} \mathrm{GAO}$, “Bulk Fuel: Actions Needed to Improve DOD’s Fuel Consumption Budget Data," p. 9.
} 
Figure 5. Defense Logistics Agency Petroleum Product Purchases in Millions of Barrels, FY1998-FY2018 ${ }^{29}$

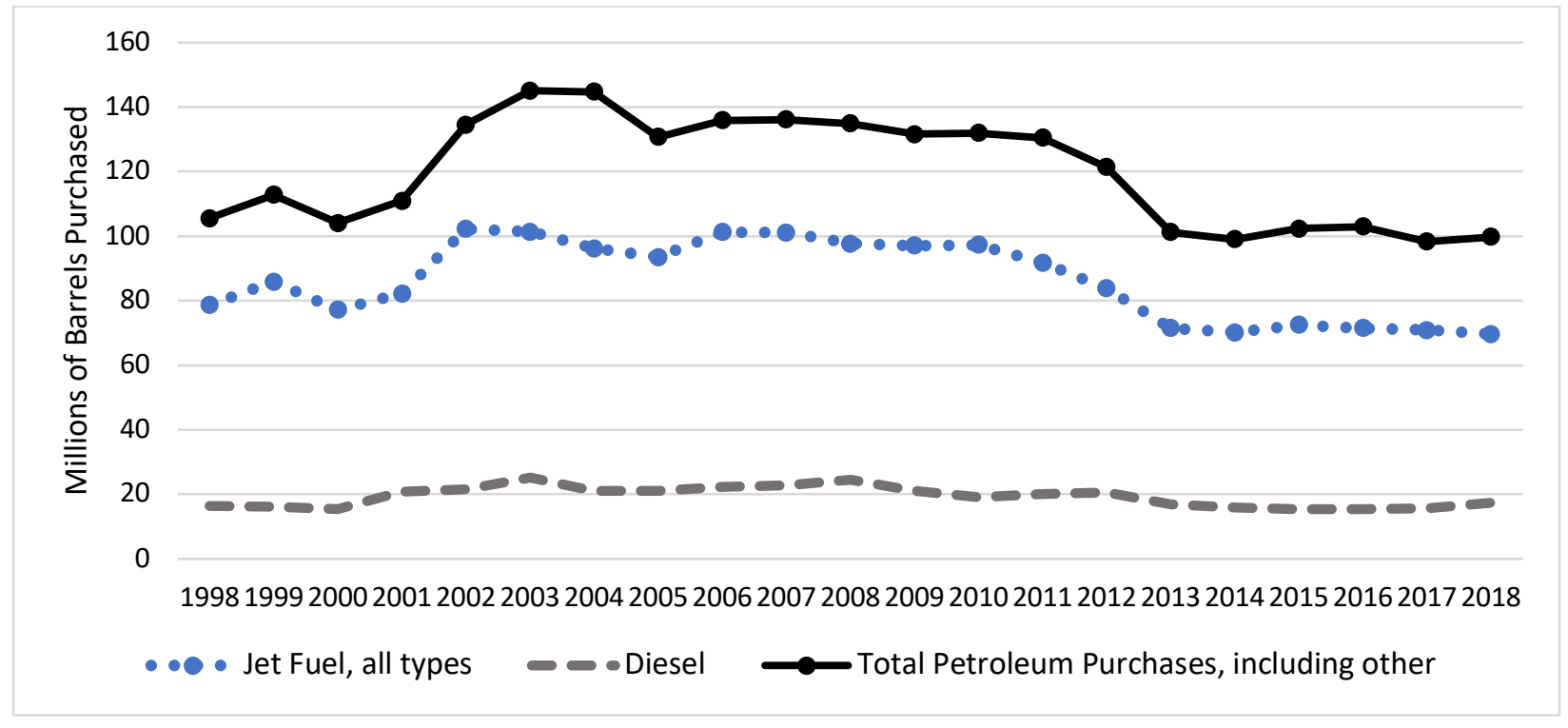

While the Defense Logistics Agency reports the purchases of petroleum products, the DOD does not report fuel consumption information to Congress in its annual budget requests. Because not all the fuel purchased is necessarily consumed in that fiscal year, an accurate estimate of emissions should be based on fuel consumption. Although the Pentagon calculates fuel consumption for internal planning purposes, this information is explicitly withheld by the DOD in its reporting to Congress. ${ }^{30}$ The Department of Energy, however, does report the fuel consumption data for mobile vehicle emissions by the US military, and energy production for facilities by fuel type from Fiscal Years 1975 to 2018. Figure 6 illustrates the mix of fossil fuels, by type from 1975 to $2018 .{ }^{31}$

\footnotetext{
${ }^{29}$ Source of Data: Reports by the Department of Defense various years. For FY2018, see Defense Logistics Agency-Energy, https://www.dla.mil/Portals/104/Documents/Energy/Publications/E Fiscal2018FactBookLowRes.pdf?ver=2019-0308-101941-663. Defense Energy Support Center, DESC, renamed the Defense Logistics Agency-Energy in FY2010. Also see https://www.dla.mil/Energy/About/Library/Publications/. Also see Thomas P. Frazier, et al, "Fuel Price Effects on Readiness," Institute for Defense Analysis, May 2014, p. C-2, https://www.ida.org/ /media/Corporate/Files/Publications/IDA.../P-5087.ashx.

${ }^{30}$ Actual and estimated future petroleum, oil, and lubricants consumption and costs for aircraft are analyzed on the DOD's OP-26A forms "POL Consumption and Costs," which explicitly states that fuel consumption data is not to be shared with Congress: "The OP-26A exhibit will not be included in justification material forwarded to Congress." Emphasis in the original. Department of Defense, Comptroller, DOD Financial Management Regulation, Chapter 3, p. 3-108, https://comptroller.defense.gov/Portals/45/documents/fmr/archive/02aarch/02a 03old.pdf. 31 The US Air Force and Army use JP-8 fuel; the Navy uses JP-5 fuel. In 2017 jet fuel consumption accounted for about 394 Trillion BTU. This was a slight decrease from the previous fiscal year, when it accounted for about 398 trillion BTUs. See the US Department of Energy, Comprehensive Annual Energy Data and Sustainability Performance, http://ctsedwweb.ee.doe.gov/Annual/Report/SiteDeliveredEnergyUseAndCostBySectorAndTypeAndFiscalY ear.aspx.
} 


\section{Figure 6. DOD Vehicle Fuel Consumption, FY1975-2018, in Millions of Gallons ${ }^{32}$}

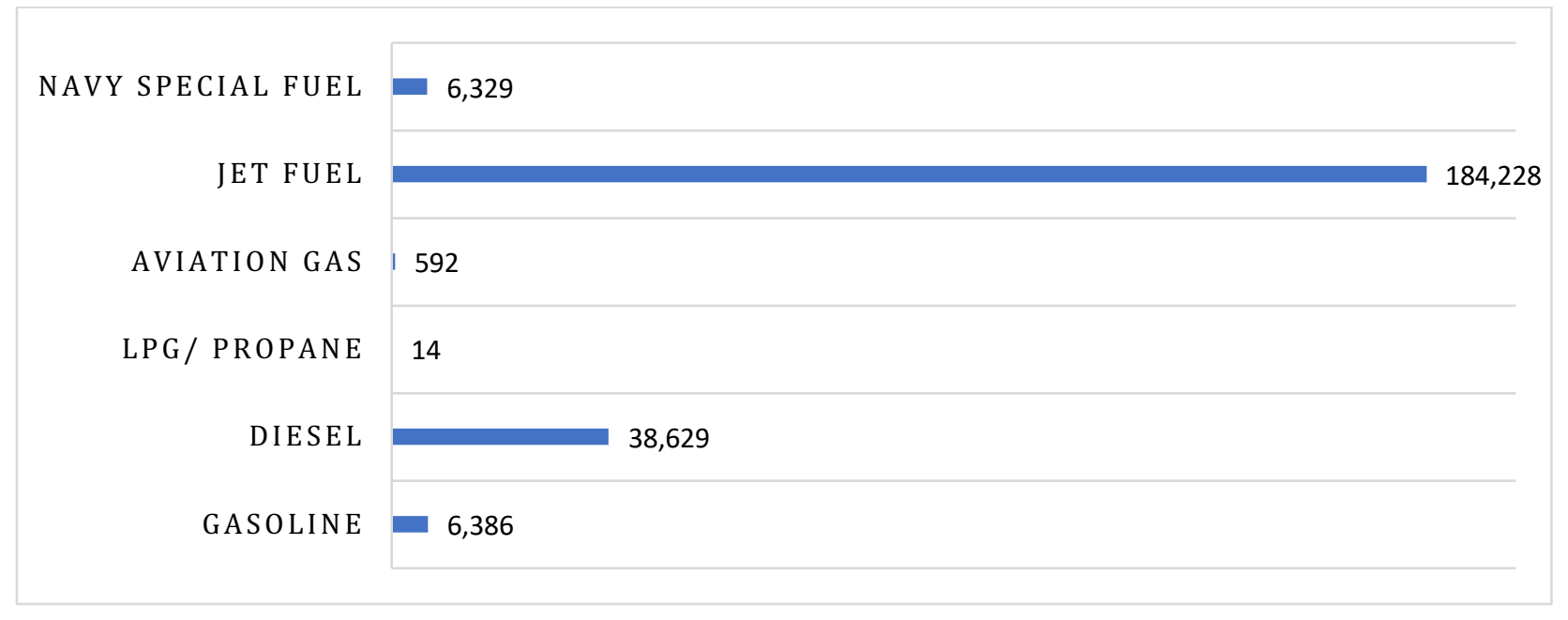

\section{Estimating US Military Greenhouse Gas Emissions and Effects of Recent Wars}

How much greenhouse gas does the US military emit, and how are those emissions distributed between base and overseas contingency operations? There are seven major sources of greenhouse gas emissions related to war and preparation for it. ${ }^{33}$ I focus here on the first two sources of military GHG emissions-overall military and war-related emissions - and briefly discuss military industrial emissions.

1. Military emissions for installations and non-war operations.

2. War-related emissions by the US military in overseas contingency operations.

3. Emissions caused by US military industry-for instance, for production of weapons and ammunition.

4. Emissions caused by the direct targeting of petroleum, namely the deliberate burning of oil wells and refineries by all parties.

5. Sources of emissions by other belligerents.

6. Energy consumed by reconstruction of damaged and destroyed infrastructure.

7. Emissions from other sources, such as fire suppression and extinguishing chemicals, including Halon, a greenhouse gas, and from explosions and fires due to the destruction of non-petroleum targets in warzones.

Because of the way emissions are reported under international rules, US military greenhouse gas emissions must be estimated. As part of the Kyoto Protocol, signed in

\footnotetext{
32 Data from the Department of Energy, https://ctsedwweb.ee.doe.gov/Annual/Report/HistoricalFederalEnergyConsumptionDataByAgencyAndEnergyType FY1975ToPresent.aspx. .

33 Biogenic emissions are excluded in these calculations. The Department of Energy does track these for recent years. See Appendix 1 for a discussion of methods and the categories of emissions included here.
} 
December 1997, the US insisted that fuel sold to ships and aircraft for international transport and for multilateral military operations, "bunker fuels," should not be counted against a country's total emissions. ${ }^{34}$ As the US Undersecretary of State Stuart Eizenstat said in testimony to Congress, the Kyoto Protocol did not limit the US:

We took special pains, working with the Defense Department and with our uniformed military, both before and in Kyoto, to fully protect the unique position of the United States as the world's only super power with global military responsibilities. We achieved everything they outlined as necessary to protect military operations and our national security.

At Kyoto, the parties ... took a decision to exempt key overseas military activities from any emissions targets, including exemptions for bunker fuels used in international aviation and maritime transport and from emissions resulting from multilateral operations, such as self defense, peacekeeping, and humanitarian relief.

This exempts from our national targets not only multilateral operations expressly authorized by the U.N. Security Council, such as Desert Storm or Bosnia, but, importantly, also exempts multilateral operations that the U.S. initiates pursuant to the U.N. Charter without express authorization, such as Grenada. ${ }^{35}$

The Intergovernmental Panel on Climate Change continues to treat national military emissions, specifically international aircraft and naval bunker fuels, differently than other emission types. ${ }^{36}$

Domestic and overseas military installations account for about 40 percent of DOD greenhouse gas emissions. ${ }^{37}$ As we see from Figures 5 and 6 above, jet fuel is a major component of US military fuel use and therefore of greenhouse gas emissions. During each air mission, aircraft puts hundreds of tons of CO2 in the air, not to mention the support activities of naval and ground based assets for these air missions. The US wars in Afghanistan and Iraq began with days of massive airstrikes. Moreover, in each case, material was flown to the war zones and bases were set up to prosecute the wars and occupations. Similarly, the US war against ISIS in Syria and Iraq, which began in August 2014, has entailed tens of thousands of aircraft sorties for various missions-from reconnaissance, to airlift, refueling, and weapons strikes. ${ }^{38} \mathrm{~A}$ B-2 Bomber on a mission from

\footnotetext{
${ }^{34}$ See Roy K. Salomon, "Global Climate Change and U.S. Military Readiness," Federal Facilities Environmental Journal, Summer 1999, vol. 10, no. 2, pp. 133-142.

35 Undersecretary of State Stuart Eizenstat, testimony, Hearing Before The Committee on Foreign Relations, 11 February 1998, https://www.govinfo.gov/content/pkg/CHRG-105shrg46812/html/CHRG105shrg46812.htm.

36 See IPCC, "Good Practice Guidance and Uncertainty Management in National Greenhouse Gas Inventories," https://www.ipcc-nggip.iges.or.jp/public/gp/bgp/2 5 Aircraft.pdf.

${ }^{37}$ Senate Appropriations Committee, Report (S. Rept. 112-168, 22 May 2012). Quoted in Moshe Schwartz, Katherine Blakely, and Donald O’Rourke, “Department of Defense Energy Initiatives: Background Issues for Congress," Congressional Research Service, 10 December 2012, p. 48.

38 See Data from US Central Command, https://www.afcent.af.mil/Portals/82/Documents/Airpower\%20summary/(U)\%20APPROVED\%20Dec\%20 2018\%20APS\%20Data.pdf?ver=2019-02-08-022732-933.
} 
Whiteman Air Force Base in Missouri might be refueled many times. For example, on 18 January 2017, two B-2 B bombers, accompanied by 15 KC-135 and KC-10 aerial refueling tankers, made a 30 hour round trip mission from Whiteman Air Force Base to Libya to drop bombs on ISIS targets in Libya. ${ }^{39}$

For purposes of illustration, Table 1, below, shows the capacities and relative fuel efficiency of several Air Force aircraft and emissions without aerial refueling. Note that the fuel economy of these aircraft is measured not in miles per gallon, but gallons per mile. ${ }^{40}$

Table 1. Examples of US Military Aircraft Jet Fuel Consumption and C02 Emissions ${ }^{41}$

\begin{tabular}{|c|c|c|c|c|c|}
\hline Aircraft & Mission & $\begin{array}{l}\text { Internal Fuel } \\
\text { Capacity in } \\
\text { pounds and } \\
\text { gallons }{ }^{42}\end{array}$ & $\begin{array}{l}\text { Range in } \\
\text { nautical miles } \\
\text { on internal fuel }\end{array}$ & $\begin{array}{l}\text { Fuel } \\
\text { consumption, } \\
\text { gallons per } \\
\text { nautical mile }\end{array}$ & $\begin{array}{l}\text { Metric Tons of } \\
\text { CO2e Emissions, } \\
\text { without aerial } \\
\text { refueling. }{ }^{43}\end{array}$ \\
\hline B-2 & Bomber & $\begin{array}{l}167,000 \mathrm{lbs} / \\
25,692 \text { gal }\end{array}$ & 6,000 & $\begin{array}{l}4.28 \\
\text { gallons/mile }\end{array}$ & 251.4 Metric Tons \\
\hline $\begin{array}{l}\text { F-35A } \\
\text { (CTOL) }\end{array}$ & $\begin{array}{l}\text { Fighter } \\
\text { bomber }\end{array}$ & $\begin{array}{l}18,499 \mathrm{lbs} / \\
2,846 \mathrm{gal}\end{array}$ & 1,199 & $\begin{array}{l}2.37 \\
\text { gallons/mile }\end{array}$ & 27.8 Metric Tons \\
\hline A-10 & $\begin{array}{l}\text { Close Air } \\
\text { Support }\end{array}$ & $\begin{array}{l}11,000 \mathrm{lbs} / \\
1,692 \mathrm{gal}\end{array}$ & 500 & $\begin{array}{l}3.38 \\
\text { gallons/mile }\end{array}$ & 17.5 Metric Tons \\
\hline KC-135R & $\begin{array}{l}\text { Refueling } \\
\text { Tanker }\end{array}$ & $\begin{array}{l}50,000 \mathrm{lbs} / \\
7,692 \mathrm{gal}\end{array}$ & $\begin{array}{l}1,500 \text { (loaded } \\
\text { with } 150,000 \\
\text { lbs of transfer } \\
\text { fuel) }\end{array}$ & 4.9 gallons/mile & 75.3 Metric Tons \\
\hline $\mathrm{KC}-46 \mathrm{~A}^{44}$ & $\begin{array}{l}\text { Refueling } \\
\text { Tanker and } \\
\text { Cargo }\end{array}$ & $\begin{array}{l}\text { Estimated } \\
16,000 \mathrm{gal}\end{array}$ & $\begin{array}{l}\text { 6,385 (loaded } \\
\text { with } 210,000 \\
\text { lbs of transfer } \\
\text { fuel) }\end{array}$ & $\begin{array}{l}\text { Estimated } 2.9 \\
\text { gallons/mile }\end{array}$ & 156.5 Metric Tons \\
\hline
\end{tabular}

The Pentagon does not publicly and regularly report its fuel consumption or greenhouse gas emissions and there is no official publicly available DOD source for all military greenhouse gas emissions. ${ }^{45}$ It is possible, however, to estimate the overall

${ }^{39}$ See Tom Demerly, "All We Know About the U.S. B-2 Bombers 30-hour Round Trip Mission to Pound Daesh in Libya," The Aviationist, 29 January 2017. https://theaviationist.com/2017/01/20/all-we-know-about-theu-s-b-2-bombers-30-hour-round-trip-mission-to-pound-daesh-in-libya/.

${ }^{40}$ Fuel use depends on the flight profile of the aircraft and other factors, such as load. By contrast with military aircraft, a commercial Boeing 747 gets about 5 gallons per mile, and can carry over 500 passengers. ${ }^{41}$ Calculated by the author from data about each aircraft. For instance, the B- 2 carries 167,000 pounds of jet fuel (almost 25,000 gallons) to travel 6,000 nautical miles (c. 6.900 miles) and is capable of mid-air refueling, taking on an additional 99,000 pounds of fuel at each refueling. The F-35A, with a combat radius estimated to be about 584 nautical miles has an internal fuel capacity of 2,761 gallons. The A-10 has an internal fuel capacity of 1,642 gallons of jet fuel has a combat radius of about 250 nautical miles.

42 Assuming each pound of jet fuel weighs an average of 6.5 pounds.

${ }^{43}$ See Appendix 1. Not including warming effects of water vapor.

44 The KC-46A can refuel itself. Boeing has not released data on its internal fuel capacity. The estimate here for fuel capacity and consumption is based on the Boeing 767-400ER range and fuel capacity.

${ }^{45}$ Some have tried to estimate the greenhouse gas emissions of the Pentagon in war. See, for instance, Nikki Reisch and Steve Kretzman, "A Climate of War: The War in Iraq and Global Warming," Oil Change International (March 2008), 
greenhouse gas of the US military using publicly available emissions data from the Department of Energy for recent years, FY2008 and FY2010-2018, and fuel consumption data for the period of 1975 to 2018. This data allows an estimate of how much of these emissions may be attributable to war.

While the Pentagon categorizes its energy use into installations and operations, the Department of Energy uses different categories, dividing government departments CO2 equivalent emissions into three categories-standard operations, non-standard operations, and biogenic emissions. ${ }^{46}$ Because the paper focuses on greenhouse gas emissions resulting from fossil fuel use, biogenic emissions are not included in the estimates; biogenic emissions are much smaller than standard and non-standard emissions.

By Department of Energy definition, non-standard operations are "vehicles, vessels, aircraft and other equipment used by Federal Government agencies in combat support, combat service support, tactical or relief operations, training for such operations, law enforcement, emergency response, or spaceflight (including associated ground-support equipment). Non-Standard operations also include the generation of electric power produced and sold commercially to other parties." ${ }^{47}$ Standard operations appear to be everything else that a department does to accomplish its functions, roles and missions. The Department of Energy reports that the US DOD has produced a total (standard and nonstandard) of 593 million metric tons of CO2 equivalent from 2010 to 2018, an average of about 66 million metric tons per year in this period, roughly the same greenhouse gas emissions of 14 million passenger cars driven for one year. ${ }^{48}$ This is also roughly equivalent to the 15 percent of total GHG emissions of the residential sector of the United States. ${ }^{49}$

Department of Energy data were used to estimate the total greenhouse gas emissions for standard and non-standard operations of the DOD from FY2001-2018 to be a total of 1,267 million metric tons of CO2 equivalent. In any one year, the Pentagon's emissions are greater than many smaller countries total greenhouse gas emissions. For example, in 2018, US DOD greenhouse gas emissions were 56 million metric tons (not including biogenic emissions) of CO2e, a reduction of 3 million metric tons over the previous year. Thus, in

http://priceofoil.org/content/uploads/2008/03/A\%20Climate\%20of\%20War\%20FINAL\%20(March\%2017 \%202008).pdf.

46 Department of Energy Federal Energy Management Program. Energy Information Agency, Comprehensive Annual Energy Data and Sustainability Performance,

http://ctsedwweb.ee.doe.gov/Annual/Report/ComprehensiveGreenhouseGasGHGInventoriesByAgencyAndF iscalYear.aspx. These categories do not correspond to the EPA Greenhouse Gas Inventory Reports, nor to the DOD categories.

${ }^{47}$ Besides the DOD, only the Department of Homeland Security performs a significant amount of "nonstandard operations." Department of Energy,

https://ctsedwweb.ee.doe.gov/Annual/Report/ComprehensiveGreenhouseGasGHGInventoriesByAgencyAnd FiscalYear.aspx.

48 There were about 110 million automobiles in the US in 2017. The EPA, which estimates that each passenger vehicle produces about 4.71 metric tons per year CO2e. https://www.epa.gov/energy/greenhouse-gasesequivalencies-calculator-calculations-and-references\#vehicles. Source for number of vehicles is the Federal Highway Administration. https://www.fhwa.dot.gov/policyinformation/statistics/2017/mv1.cfm. ${ }^{49}$ Source: EPA, https://cfpub.epa.gov/ghgdata/inventoryexplorer/\#allsectors/allgas/econsect/current. 
FY2017, Pentagon emissions were greater than Finland, which emitted 46.8 million metric tons, Sweden, which emitted 50.8 million metric tons, and Denmark, which emitted 33.5 million metric tons of CO2e. In FY2018, US DOD emissions were 56 million metric tons of C02equivalent, greater than the entire emissions of most countries in the world. ${ }^{50}$

\section{Figure 7. Estimate of DOD Greenhouse Gas Emissions, Millions of Metric Tons C02e from Total and Non-Standard DOD operations, FY2000-2018}

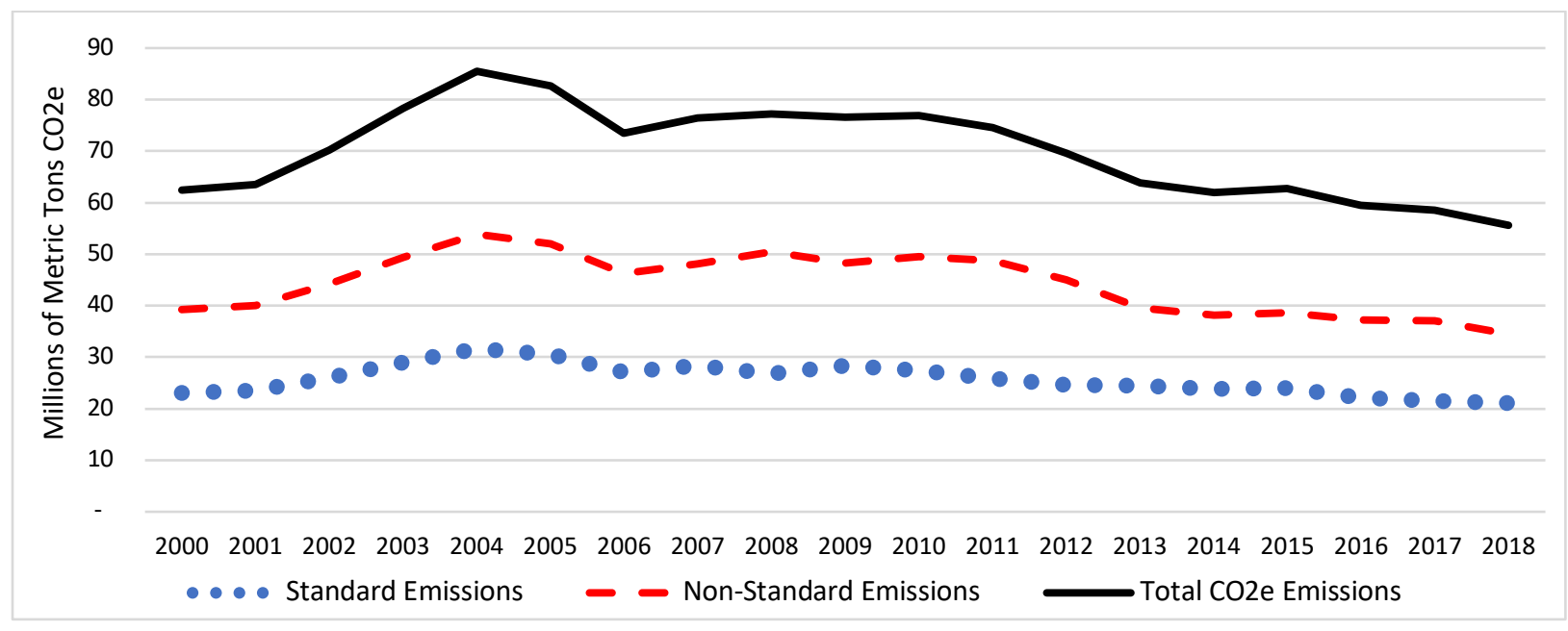

How much of the total GHG emissions should be attributed to US post-9/11 wars? As discussed in Appendix 1, there are various ways to estimate Pentagon greenhouse gas emissions. The estimate given here of greenhouse gas emissions in the major wars is based on the proportion of fuel use by Central Command, which is the command responsible for operations in Afghanistan and Iraq and Syria. In FY2014 (see figure 4) this was about 24 percent of the total non-standard operational fuel consumption by the DOD. But because US counterterror operations are underway all over the world (in about 80-90 countries) the Central Command is not the only war zone in the global war on terror. The portion of all greenhouse gas emissions related to Central Command including overseas contingency operations, and the Global War on Terror, is estimated to be about 35 percent of total greenhouse gas emissions for non-standard and standard operations.

\footnotetext{
${ }^{50}$ M. Muntean, D. Guizzardi, et al, Fossil CO2 Emissions of All World Countries: 2018 Report (Joint Research Centre, European Commission, 2018), https://ec.europa.eu/jrc/en/publication/eur-scientific-and-technicalresearch-reports/fossil-co2-emissions-all-world-countries-2018-report.

51 Based on Department of Energy data. Methods are detailed in Appendix 1. https://ctsedwweb.ee.doe.gov/Annual/Report/ComprehensiveGreenhouseGasGHGInventoriesByAgencyAnd FiscalYear.aspx.
} 
Table 2. Estimated DOD and War Related Overseas Contingency Operation Greenhouse Gas Emissions, Millions of Metric Tons C02e, FY2001-2018 ${ }^{52}$

\begin{tabular}{|l|c|l|}
\hline & $\begin{array}{l}\text { Total DOD CO2e } \\
\text { Emissions } \\
\text { in Millions of Metric Tons }\end{array}$ & $\begin{array}{l}\text { OCO-related CO2e } \\
\text { Emissions } \\
\text { in Millions of Metric Tons }\end{array}$ \\
\hline Standard & 466 & 163 \\
\hline $\begin{array}{l}\text { Non-standard (directly } \\
\text { support combat) }\end{array}$ & 801 & 280 \\
\hline Total FY2001-2018 & 1,267 & 443 \\
\hline
\end{tabular}

Figure 8, below, illustrates trends in DOD greenhouse emissions from FY1975 to FY2018. Several trends are worth noting. First, estimated Pentagon emissions are correlated with hot war and cold war. When the US is at war or engaged in exercises and war games in preparation for war, emissions are higher than when the US is relatively less mobilized. During the Reagan military build-up of the 1980s fuel use, and therefore greenhouse gas emissions, rose. Following the end of the Cold War, apart from a spike in emissions during the 1991 Gulf War, not only was there a reduction in military spending, there was a significant reduction in GHG emissions through the 1990s. Following the 9/11 attacks and the start of the wars in Afghanistan and Iraq, US emissions rose dramatically. Fuel use and emissions correlate with the phases of operations in both war zones, tracking troop surges and withdrawals during the post-9/11 wars.

Figure 8. Estimated Total DOD Greenhouse Gas Emissions, C02e, FY1975-2018 53

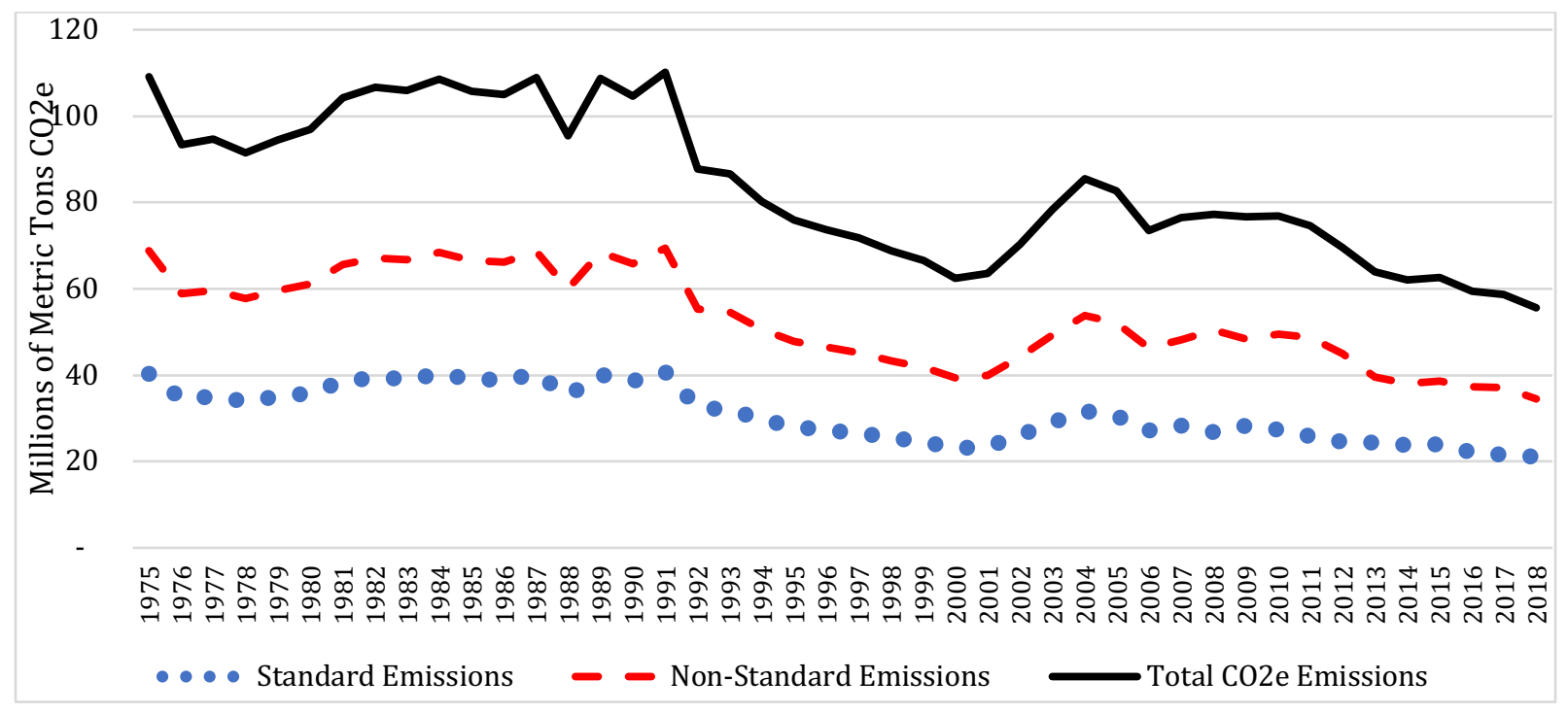

\footnotetext{
${ }^{52}$ Rounded to the nearest Million Metric Ton. Based on Department of Energy data.

${ }^{53}$ CO2e calculated for Carbon Dioxide, Methane and Nitrous Oxide. For FY2008 and FY2010-2018, this estimate uses the Department of Energy figures. The other years are estimates calculated from Department of Energy fuel consumption data. "Comprehensive Annual Energy Data and Sustainability Performance," Annual Reports.
} 
Second, the US reduced its fuel use and emissions overall from 1975 to 2018. This correlates with, and was likely caused by, four factors: base closures, decreased use of greenhouse gas intensive fuels at bases and installations, fewer and smaller military exercises, and more efficient vehicles and operations. These are discussed in turn.

Following the Cold War, the number of US military bases were reduced in successive waves of Base Realignment and Closure (BRAC) from 1988 through 2005. Figure 9 shows the trend in DOD facilities energy use from FY1975 to FY2018. Energy consumption at military facilities declined more than 50 percent during this period, with the biggest declines in the 1990s. In 1989 there were about 1,600 US military bases all over the world, including a large conventional and nuclear US military presence in Europe. Today, there are about 800 US military bases and installations in the world. ${ }^{54}$ The most recent BRAC process, from 2005 to 2011, led to an overall decline in the number of DOD buildings and other structures-from over 600,000 individual buildings and structures located on more than 30 million acres of land before the BRAC in FY2003 to about 585,800 buildings and structures on 26.9 million acres in FY2018.55

\section{Figure 9. Total DOD Facility Energy Use, Billion BTU, FY1975-2018, All Fuels. ${ }^{56}$}

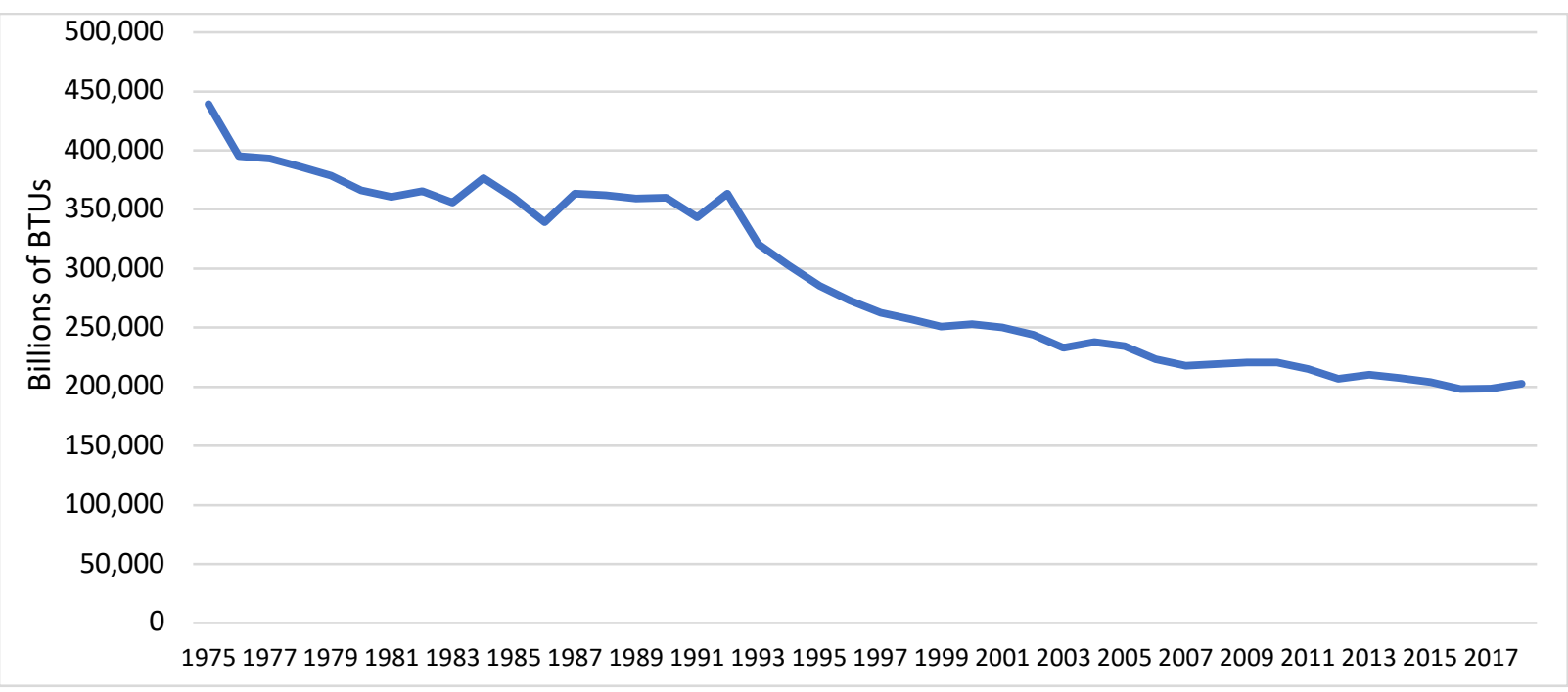

\footnotetext{
54 Vine, "Lists of U.S. Military Bases Abroad, 1776-2019," American University Digital Research Archive, 2019, https://doi.org/10.17606/vfyb-nc07. Department of Defense, "DoD Base Realignment and Closure, BRAC Rounds (BRAC 1988, 1991, 1993, 1995 \& 2005), Executive Summary," March 2019, https://comptroller.defense.gov/Portals/45/Documents/defbudget/fy2020/budget justification/pdfs/05 B RAC/BRAC Exec Sum_J-Book FINAL.pdf.

55 Sources: Department of Defense Base Structure Reports for FY2003 and FY2018. See, respectively: for FY2003, https://archive.defense.gov/news/Jun2003/basestructure2003.pdf; and FY2018, https://www.acq.osd.mil/eie/Downloads/BSI/Base\%20Structure\%20Report\%20FY18.pdf.

56 Source: Department of Energy, All DOD facilities combined, https://ctsedwweb.ee.doe.gov/Annual/Report/HistoricalFederalEnergyConsumptionDataByAgencyAndEner gyTypeFY1975ToPresent.aspx.
} 
Further, over the long term, the mix of fuel uses at military facilities, bases and other installations changed.$^{57}$ In FY 1975, coal and fuel oil, were a significant portion of DOD energy use. In FY1975, facilities used a total of 439,228 Billion BTUs.

Figure 10. DOD Facilities Energy Use, FY1975 in Billions of BTUs ${ }^{58}$

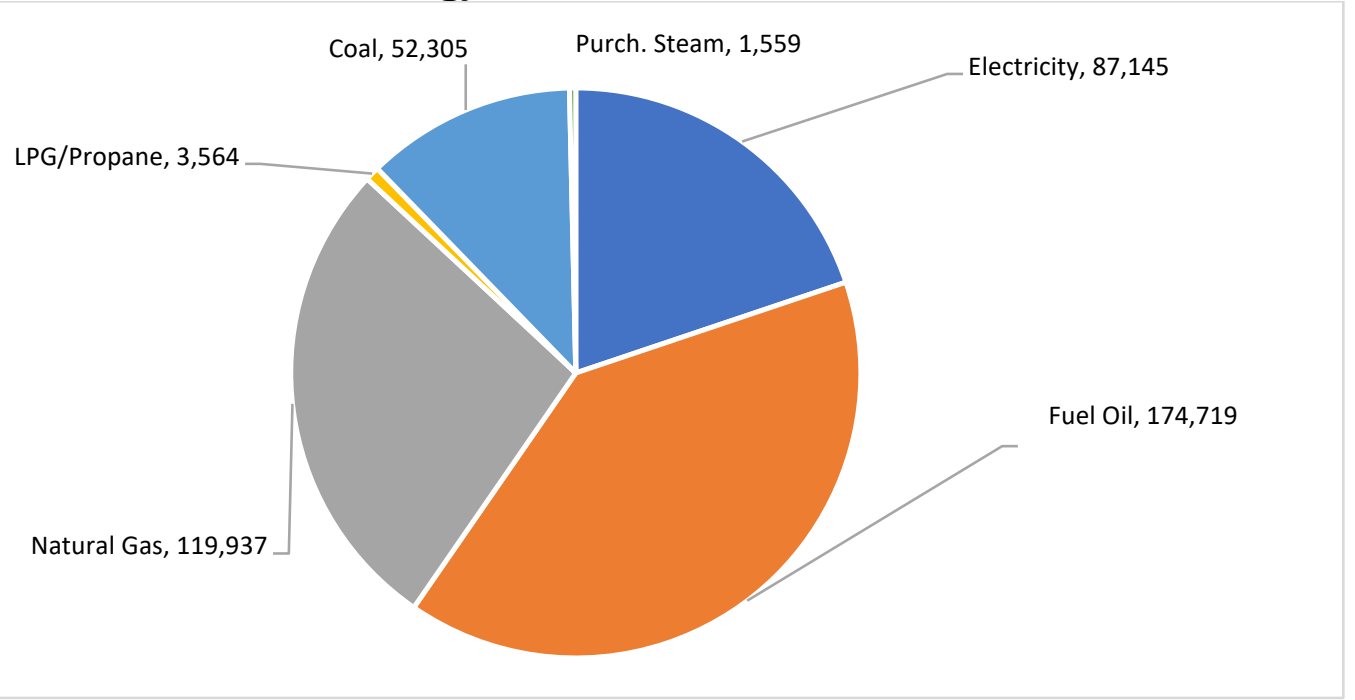

By FY 2018, as Figure 11 illustrates, US military facilities were, overall, consuming much less energy, a total of 202,283 Billion BTUs, a reduction of more than 50 percent.

\section{Figure 11. DOD Facilities Energy Use, FY2018 in Billions of BTUs ${ }^{59}$}

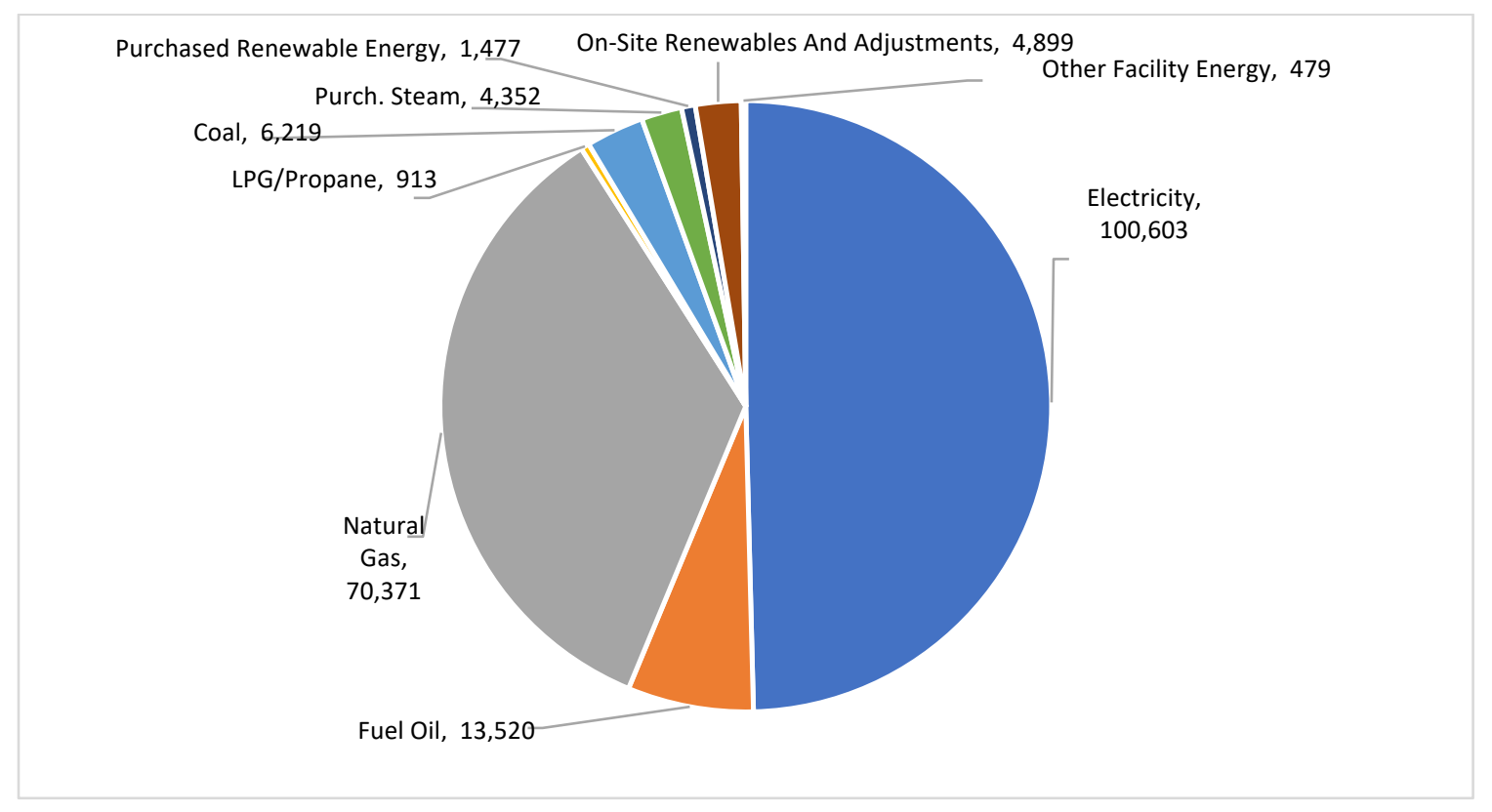

57 Source: Department of Energy data.

58 Source: Department of Energy data.

${ }^{59}$ Source: Department of Energy data. 
By 2018 the DOD was purchasing a greater portion of their energy needs as electricity. Coal and fuel oil consumption - the most GHG intensive fuels-dramatically decreased, while natural gas, with its lower GHG intensity, was a greater proportion of energy. Coal power use at facilities has dramatically declined, from 12 percent of BTUs in FY1975 to 3 percent in FY2018. Figure 12 illustrates the trends in natural gas and coal greenhouse gas emissions at DOD facilities. ${ }^{60}$ Similarly, fuel Oil has declined as a share of BTUs from 40 percent in FY1975 to 7 percent in FY2018. Renewable energy was added to the mix of energy sources at facilities with on-site production in 2008, and purchases of renewable energy for DOD facilities beginning in FY2012. Purchased and on-site renewables comprised 3 percent of DOD facilities energy use in FY2018.

Figure 12. DOD Facilities C02e Emissions of Natural Gas and Coal, FY1975-2018, in Metric Tons ${ }^{61}$

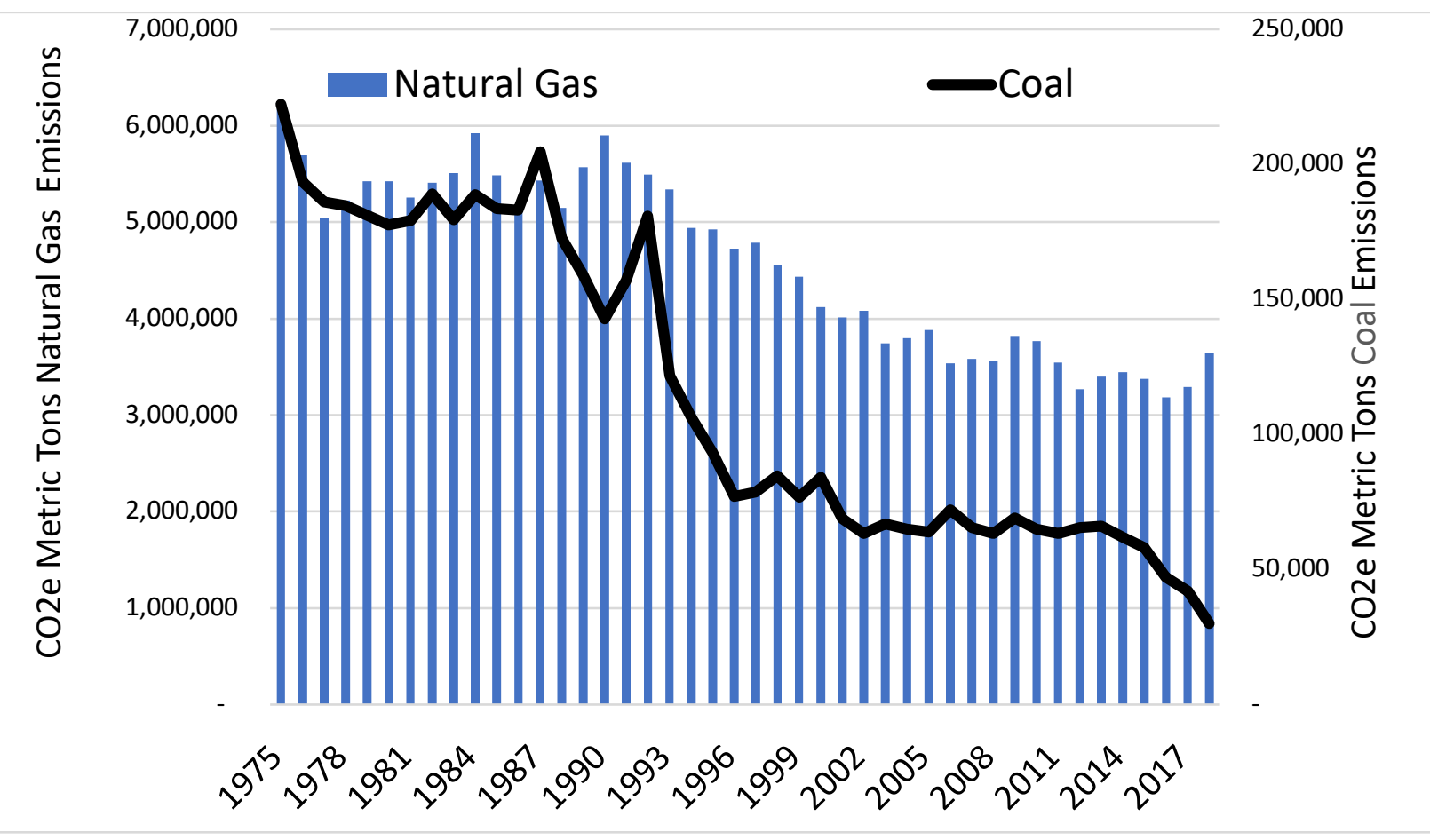

The size and number of US military exercises with NATO and other allies have declined since the end of the Cold War and there was a steep decline in the number of US forces deployed in Europe at the end of the Cold War. ${ }^{62}$ Some reductions in military exercises have also been made possible as the military relies on computer simulations for some exercises. For instance, in 2016, NATO planned 240 military exercises. In 2017, NATO

\footnotetext{
${ }^{60}$ Department of Energy,

https://ctsedwweb.ee.doe.gov/Annual/Report/HistoricalFederalEnergyConsumptionDataByAgencyAndEner gyTypeFY1975ToPresent.aspx.

${ }^{61}$ Calculated from Department of Energy data.

${ }^{62}$ See Angela O'Mahony, et al, U.S. Presence and the Incidence of Conflict (Santa Monica: RAND Corporation, 2018) p. 14,

https://www.rand.org/content/dam/rand/pubs/research reports/RR1900/RR1906/RAND RR1906.pdf.
} 
conducted 108 military exercises, in 2018, 103 exercises, and NATO planned to conduct 102 exercises in 2019.63

There has also been greater efficiency and conservation in military vehicles and equipment and operations. For instance, there have been improvements in the efficiency of aircraft and other tactical and non-tactical vehicles, operational efficiencies (such as reducing engine idling time), and the retirement of less efficient vehicles. ${ }^{64}$ Since the end of the Cold War, the US has retired and decommissioned eight non-nuclear aircraft carriers, so that the Navy's entire fleet of 11 aircraft carriers is nuclear powered.

The estimates above focus on DOD emissions. Yet, a complete accounting of the total greenhouse gas emissions related to war, and preparation for it, would include the GHG emissions of military industry. Military industry directly employs about 14.7 percent of all people in the US manufacturing sector. ${ }^{65}$ Assuming that the relative size of direct employment in the domestic US military industry is an indicator for the portion of the military industry in the US industrial economy, the share of US greenhouse gas emissions from US based military industry is estimated to be about 15 percent of total US industrial greenhouse gas emissions. ${ }^{66}$ If half of current military related emissions are attributable to the post-9/11 wars, then US war manufacturing has emitted about 2,600 million megatons of CO2 equivalent greenhouse gas from 2001 to 2017, averaging 153 million metric tons of C02e each year. Of course, a much more detailed analysis of the greenhouse gas emissions of the military industrial sector is required. Nevertheless, this estimate may be conservative, since some military-industrial applications (such as armored vehicle and jet aircraft manufacturing) will likely, on average, be more greenhouse gas intensive than many other forms of manufacturing.

\footnotetext{
${ }^{63}$ NATO, "Key Allied and NATO Exercises in 2019,"

https://www.nato.int/nato static fl2014/assets/pdf/pdf 2019 02/1902-factsheet exercises en.pdf. Also see https://www.nato.int/nato static fl2014/assets/pdf/pdf_2018_04/20180425_1804-

factsheet exercises en.pdf and

https://www.nato.int/nato_static_fl2014/assets/pdf/pdf_2016_07/20160704_1607factsheet exercises en.pdf/.

${ }^{64}$ See for instance, US Department of Energy, "Air Force Achieves Fuel Efficiency Through Industry Best Practices," https://www.energy.gov/sites/prod/files/2013/10/f3/af fuelefficiency.pdf and Christopher A. Mouton, et. al, Fuel Reduction for the Mobility Air Forces (Santa Monica: RAND Corporation, 2015). https://www.rand.org/content/dam/rand/pubs/research reports/RR700/RR757/RAND_RR757.pdf. 65 In 2016, 839,171 people worked in US Defense Industries out of a total of 12,348,100 jobs total in the US manufacturing sector. See Deloitte, "2017 Aerospace and Defense Sector Export and Labor Market Study," p. 13. https://www2.deloitte.com/content/dam/Deloitte/us/Documents/manufacturing/us-2017-us-A\&Dexports-and-labor-market-study.pdf and the US Bureau of Labor Statistics https://www.bls.gov/emp/tables/employment-by-major-industry-sector.htm. Louis Uchitelle, “The U.S. Still Leans on the Military-Industrial Complex," The New York Times, 22 September 2017, https://www.nytimes.com/2017/09/22/business/economy/military-industrial-complex.html. In 1992, about 14.4 percent of manufacturing jobs were in military industries. Ann Markeson and S. S. Costigan, eds., Arming the Future: A Defense Industry for the $21^{\text {st }}$ Century (New York: Council on Foreign Relations, 1999) p. 341. Manufacturing accounts for most of the industrial sectors greenhouse gas emissions according to the annual EPA Inventory of U.S. Greenhouse Gases and Sinks, 1990-2017. The most recent is found at https://www.epa.gov/sites/production/files/2019-02/documents/us-ghg-inventory-2019-main-text.pdf. ${ }^{66}$ This does not include indirect jobs and therefore indirect military related emissions.
} 
Figure 13. Greenhouse Gases Attributable to Military Industry from 2001-201767

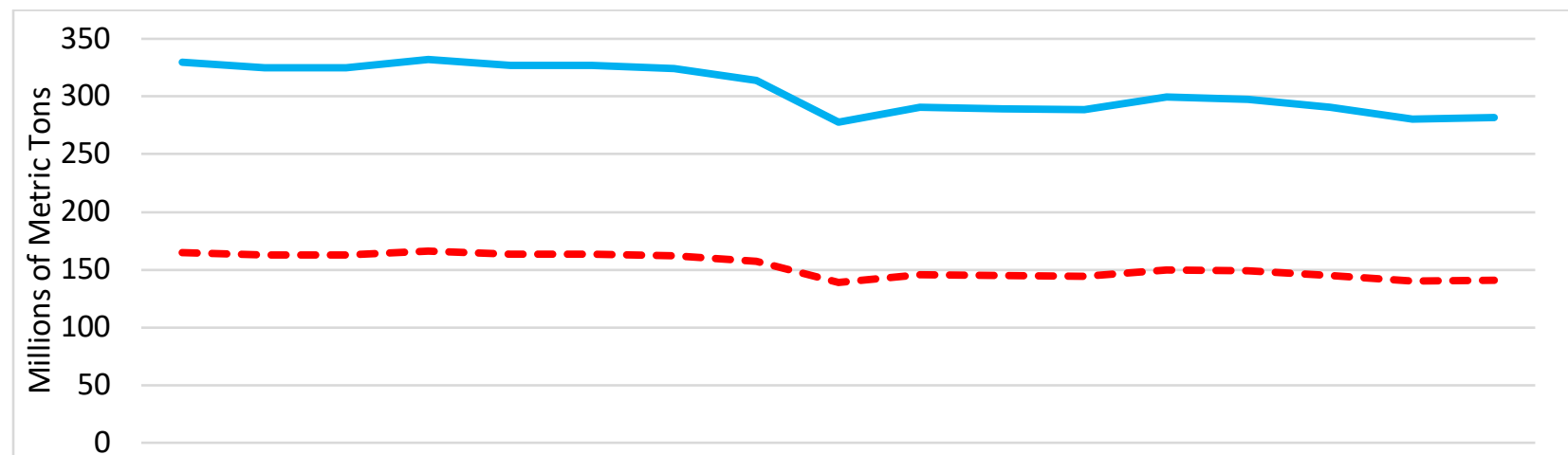

20012002200320042005200620072008200920102011201220132014201520162017

GHG Attributed to Military Industry _ _ - Estimate of Military Industry GHG attributable to war

Other emissions sources that are not calculated or estimated here may also be significant sources of war related greenhouse gasses. Specifically, it was not possible to estimate the emissions due to the burning of oil by sabotage and destruction of oil infrastructure by belligerents, the energy consumed by reconstruction, in particular in making cement, and emissions from other sources. Of these, the emissions from burning oil infrastructure in Iraq and Syria may be the largest. NATO tankers were often attacked by militants and burned during their transit through Pakistan into Afghanistan. In the 2003 invasion of Iraq, oil wells were set alight by the Iraqi military and burned for several months. ${ }^{68}$

Oil infrastructure was targeted again in 2015, when the US bombed oil infrastructure in Iraq and Syria as a means of reducing ISIS revenue. And when ISIS retreated, it set oil wells and pipelines on fire in Iraq and Syria. ${ }^{69}$ In many cases, these fires burned for several months. Starting in September 2014, the US targeted tanker trucks and oil refinery and

${ }^{67}$ Calculated from U.S. Greenhouse Gas Emissions by Economic Sector with Electricity-Related Emissions Distributed (MMT CO2Eq). EPA “Inventory of U.S. Greenhouse Gases and Sinks, 1990-2017."

68 Iraq did the same in the 1991 Gulf War, setting oil production facilities in Kuwait alight as they retreated. In April and May 1991, an estimated 3 million barrels of oil were burning each day, 1 or 2 million tons of carbon dioxide, or about 2 percent of worldwide $\mathrm{CO} 2$ emissions from fossil fuel and biomass. Congressional Research Service, "The Environmental Impact of the Gulf War," for the United States Senate Committee on Environment and Public Works Gulf Pollution Task Force, March 1992, pp. 10 and 24. Out of the 82 million barrels released on land and at sea during the 1991 Gulf War, an estimated 11 million barrels of oil spilled into the Persian Gulf, coating the coastlines of not only Kuwait, but other countries in the Gulf, including Saudi Arabia, and Iran. More than a decade later, much of that oil remained in coastal areas. See Erich R. Gundlach, John C. McCain, and Yusef H. Fadallah, "Distribution of Oil Along the Saudi Arabian Coastline (May/June 1991) as a Result of the Gulf War Oil Spills," Marine Pollution Bulletin, vol. 27, (1993) pp. 93-96. Dagmar Schmidt-Etkin, "Spill Occurrences: A World Overview," in Mervin Fingas, ed., Oil Spill Science and Technology (Amsterdam: Elsevier, 2011) p. 8 and Jacqueline Michel, "1991 Gulf War Oil Spill," in Fingas, ed. Oil Spill Science and Technology, pp. 1127-1132.

${ }^{69}$ Saif Hameed and Dominic Evans, "Islamic State Torches Oil Field Near Tikrit as Militia Advances," Reuters, 5 March 2015, https://www.reuters.com/article/us-mideast-crisis-iraq-idUSKBN0M10Z420150305. 
storage sites controlled by ISIS as a means of cutting off their revenue stream. In October 2015, the US attacked more oil producing ISIS controlled oil infrastructure. ${ }^{70}$

In addition, it would be possible, using the methods used here for US military greenhouse gas emissions, to calculate the emissions of other belligerents. More than 60 countries joined the US in their war in Afghanistan, 37 fought with the US in the Iraq War, and more than 60 were allied with the US in the war against ISIS. These emissions may be substantial.

Finally, a full assessment of the climate change consequences of war would include the loss of actual and future carbon sequestration due to war-related deforestation. Deforestation may occur as people displaced by war use forests for shelter and fuel. In some wars, such as the US Civil War and the Vietnam War, forests were deliberately burned to deprive adversaries of places to hide. In Afghanistan, war caused migration and illegal logging appear to be the chief cause of deforestation. The causes of deforestation in Iraq are complex but also include war. ${ }^{71}$

\section{National Security Threats Posed by Oil Dependency and Climate Change}

Three national security concerns overlap. First, the US government has long been concerned about dependency on Persian Gulf oil. At the same time, some portion of the military's operational fuel consumption is related to missions associated with protecting access to oil and protecting the regimes that assure US and global access to oil. Some believe this mission is vital, while others question whether it is still necessary.

The centrality of oil in US calculations was underscored recently when, after the US pulled troops out of Syria, US Secretary of Defense Mark Esper has said that the US will defend oil fields in Syria to "ensure that we can deny ISIS access to the oil fields."72 President Trump expanded on this the next day:

Look, we don't want to keep soldiers between Syria and Turkey for the next 200 years. They've been fighting for hundreds of years. We're out. But we are leaving soldiers to secure the oil. And we may have to fight for the oil.

\footnotetext{
70 This was known as Operation Tidal Wave II. See Matthew Reed, "Blowing up the Islamic State's Oil Company," Foreign Policy, 26 October 2016, https://foreignpolicy.com/2016/10/26/blowing-up-the-islamicstates-oil-company-isis-abu-sayyaf/.

71 Zabihullah Ghazi, "Afghanistan's Forest Cover Illegally Stripped Away," Environment New Service, 29 August 2013, https://ens-newswire.com/2013/08/29/afghanistans-forest-cover-illegally-stripped-away/. UN Environment, "Salvaging Iraq's Remaining Wilderness," 10 July 2018.

https://www.unenvironment.org/news-and-stories/story/salvaging-iraqs-remaining-wilderness.

${ }^{72}$ Michael Birnbaum and Missy Ryan, "U.S. Defense Secrtary Mark Esper Says U.S. Will Leave Forces in Syria to Defend Oil Fields from Islamic State," The Washington Post, 25 October 2019, https://www.washingtonpost.com/world/us-defense-secretary-mark-esper-says-us-will-leave-forces-insyria-to-defend-oil-fields-from-islamic-state/2019/10/25/fd131f1a-f723-11e9-829d87b12c2f85dd story.html.
} 
It's okay. Maybe somebody else wants the oil, in which case they have a hell of a fight. But there's massive amounts of oil.

And we're securing it for a couple of reasons. Number one, it stops ISIS, because ISIS got tremendous wealth from that oil. We have taken it. It's secured....

I don't want to leave 1,000 or 2,000 or 3,000 soldiers on the border. But where Lindsey [Graham] and I totally agree is the oil. The oil is, you know, so valuable. For many reasons. It fueled ISIS, number one. Number two, it helps the Kurds, because it's basically been taken away from the Kurds. They were able to live with that oil. And number three, it can help us, because we should be able to take some also. And what I intend to do, perhaps, is make a deal with an ExxonMobil or one of our great companies to go in there and do it properly. Right now it's not big. It's big oil underground but it's not big oil up top. Much of the machinery has been shot and dead. It's been through wars. But -- and -- and spread out the wealth. But no, we're protecting the oil, we're securing the oil. Now that doesn't mean we don't make a deal at some point. ${ }^{73}$

Second, the DOD has become increasingly concerned that climate change poses threats and challenges to the military as an institution, specifically to military installations and operations. This is coupled with a concern that fuel dependency makes the US military vulnerable. The US has reduced fuel consumption so that it is less dependent on fossil fuel.

And third, the Pentagon is concerned with the threats climate change pose to international security, namely massive migration and potentially war. As US Navy Admiral Samuel J. Locklear II, then chief of US Pacific Command said in 2013, climate change caused instability "is probably the most likely thing that is going to happen ... that will cripple the security environment, probably more likely than the other scenarios we all often talk about."74

However, the military seems unaware of how much its efforts to protect access to Persian Gulf Oil, its other military operations, including war and fuel consumption at installations, are a major driver of greenhouse gas emissions, and therefore ultimately of climate change.

In sum, the DOD assumes that climate change will be a disaster for the institution and the planet no matter what they do, even as they believe that they must continue to protect access to Persian Gulf oil so that the US and the rest of the world can burn as much oil as it

\footnotetext{
${ }^{73}$ Dana Farrington, "Read: Trump Announcement on Baghdadi's Death," 27 October 2019, https://www.npr.org/2019/10/27/773842999/read-trump-statement-on-baghdadis-death.

${ }^{74}$ Bryan Bender, "Chief of US Pacific Forces Calls Climate Biggest Worry," The Boston Globe, 9 March 2013, https://www.bostonglobe.com/news/nation/2013/03/09/admiral-samuel-locklear-commander-pacificforces-warns-that-climate-change-top-threat/BHdPVCLrWEMxRe9IXJZcHL/story.html.
} 
wants at as low a price per barrel as possible. The Pentagon focuses their efforts on adapting to climate change, as Admiral Locklear calls it "consequences management," by preparing for climate caused insecurity, even as they continue to ensure that Americans continue to have relatively inexpensive access to imported oil.

\section{Protecting Persian Gulf Oil: Is This Still a Vital Mission?}

The concern about access to oil is twofold. First, at a tactical level, the US wants to control who has access to oil and the profits from exploiting oil reserves. The US has been willing to use military resources to destroy infrastructure or blockade oil exports.

Second, at the strategic level, the US economy remains reliant on oil and is concerned about the flow and price of oil. The military has defended against several scenarios regarding a cut-off of Persian Gulf oil. The first scenario is the threat that a hostile power would gain control of oil in the Persian Gulf-for instance by occupying Saudi Arabia and Kuwait or by blocking the Strait of Hormuz-and be able to control world supply and increase the price of oil. In response to the first fear, the US created the Strategic Petroleum Reserve in 1975 and the Rapid Deployment Force (RDF) in 1979, whose specific mission was to defend US interests in the Middle East, including oil. In January 1983, when US commands were reorganized, the RDF became US Central Command (CENTCOM).

\section{Figure 14. Zones of US Military Commands}

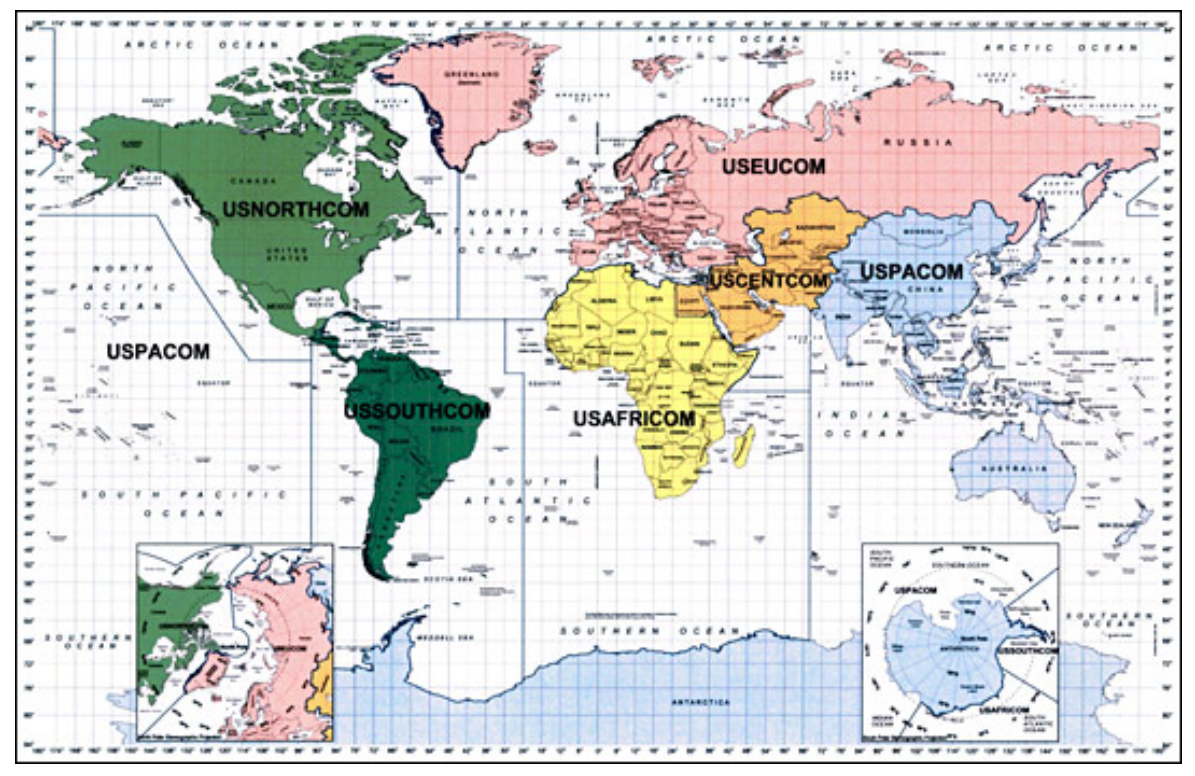

When Iraq invaded Kuwait in 1990, the Bush Administration reiterated the importance of oil in the region in National Security Directive 45. "U.S. interests in the Persian Gulf are vital to the national security. These interests include access to oil and the security and stability of key friendly states in the region. The United States will defend its vital interests in the area, through the use of U.S. military force if necessary and appropriate, against any 
power with interests inimical to our own." 75 In 1991, the US evicted Iraq from Kuwait not only because the Iraqi invasion of Kuwait was illegal, but also in part because it feared that Iraq posed a threat to Saudi Arabia, and thus to American access to oil.

Since then, the US has stationed large numbers of troops in the Persian Gulf at Army, Navy, and Air Force bases. The Afghan and Iraq wars increased the US presence in the region, as well as US military petroleum consumption. In late 2008, in addition to the concern that a local state might try to control the flow of oil from the Persian Gulf, President George W. Bush added the concern that extremists might control oil and try to blackmail the US: "You can imagine them saying, 'We're going to pull a bunch of oil off the market to run your price of oil up unless you do the following. And the following would be along the lines of, well, 'Retreat and let us continue to expand our dark vision.'"76

The idea that the US has to protect the global flow of oil, and more specifically oil from the Persian Gulf, has largely been taken for granted by the US military and national security experts. A report by the Council on Foreign Relations noted in 2006, "Until very low levels of dependence are reached, the United States and all other consumers of oil will depend on the Persian Gulf."77

As the US has diversified its oil sources and overall demand has declined, the US has become less dependent on Persian Gulf oil in recent decades. In 2018, according to the US Energy Information Administration, imported oil provided about 11 percent of total US oil consumption, the lowest level of imports since 1957.78 Specifically, in 2001, the US imported 2,664 barrels per day from the Persian Gulf; in 2018, the US imported 1,472 barrels per day from the Persian Gulf. ${ }^{79}$ Overall, in 2018, Persian Gulf sources accounted for about 20 percent of all US oil imports.

Perhaps in part because dependence on Persian Gulf oil has declined significantly since 2006, some analysts have recently questioned whether the large US presence in the Persian Gulf region, and the infrastructure in Europe that supports it, is necessary. ${ }^{80}$ The argument

\footnotetext{
75 National Security Directive 45, 20 August 1990, https://fas.org/irp/offdocs/nsd/nsd 45.htm.

76 Peter Baker, "Bush Says U.S. Pullout Would Let Radicals Use Oil as a Weapon," Washington Post, 5

November 2006. http://www.washingtonpost.com/wpdyn/content/article/2006/11/04/AR2006110401025.html.

${ }^{77}$ Council on Foreign Relations, National Security Consequences of Oil Dependency: Report of an Independent Task Force (Washington, DC: Council on Foreign Relations, 2006), p. 29. https://cfrd8-

files.cfr.org/sites/default/files/report pdf/0876093659.pdf.

78 US Energy Information Administration, https://www.eia.gov/tools/faqs/faq.php?id=32\&t=6.

${ }^{79}$ Source: US Energy Information Administration,

https://www.eia.gov/dnav/pet/hist/LeafHandler.ashx?n=PET\&s=MCRIMUSPG2\&f=A. The total level of US oil importation has also declined in recent years.

${ }^{80}$ See Glaser and Kelanic, eds., Crude Strategy; John Glazer, "Does the U.S. Military Actually Protect Middle East Oil?" Cato Institute, 9 January 2017. https://www.cato.org/publications/commentary/does-us-militaryactually-protect-middle-east-oil; Emma Ashford, "Unbalanced: Rethinking America's Commitment to the Middle East," Security Studies Quarterly, vol. 12, no. 1 (Spring 2018), pp. 127-148. Also see Milton R. Copulos, "America's Achilles Heel: The Hidden Cost of Imported Oil," The National Defense Council Foundation, (Washington, DC: October 2003).
} 
is that the US is less dependent on Persian Gulf oil than in the past, that price shocks will not necessarily be as severe if oil flows were disrupted, and that even if a single country controlled supplies, they would still want to sell the oil. The exception to the latter is Iraq, which burned Kuwaiti Oil fields when they retreated from Kuwait in 1991 and the Islamic State, which burned oil facilities as they retreated from 2015-2018. In any case, the argument goes, even if the US were completely absent from the Gulf, the US could return to the Gulf and restore oil flow at some later point. US forces in the region have already declined from their peak of about 230,000 troops in $2008 .^{81}$

What would happen in the worst-case scenario-if oil flows from the Persian Gulf were curtailed or ceased for a week or several months? There would be some disruption to the US economy, but the economy would not collapse if oil flows from the Middle East were disrupted for some time. It is arguable that a total loss of Gulf oil for up to three months, would be, at worst, quite expensive. In the short term, it is likely that the US would adaptas it did when the oil imports from Iraq and Kuwait were halted after Iraq's invasion of that Kuwait in 1990. The principal reaction of world markets would be an increase in the price of oil.

This would not be a devastation for three reasons. First, the US is less dependent on Persian Gulf oil than in the past; the US has a more diverse supply network of petroleum, including increases in domestic production, and increased imports from Canada and other countries. Second, the US has a strategic oil reserve containing 727 million barrels of oil, which could carry the US through several months of shortages in supply. And third, and perhaps most important, overall demand for oil has decreased in the US. Petroleum consumption peaked in 2005 at 40 percent of total US energy consumption and has declined 10 percent since then. In 2017, petroleum accounted for 37 percent of US energy consumption. ${ }^{82}$ China is more vulnerable than the US to Persian Gulf oil supply disruptions.

Nevertheless, economists tend to associate oil price shocks due to restrictions on the flow of oil (such as the Arab Oil Embargo) with recessions. This is true. Yet, because military spending is less productive compared to other forms of spending-say on education, health care, infrastructure, or renewable energy-military spending is arguably an overall drag on the US economy because it produces fewer jobs than spending on other sectors. Which raises the question of whether, in protecting against a potential oil price increase, the US does more harm than it risks by not defending access to Persian Gulf oil. In sum, the Persian Gulf mission may not be as necessary as the Pentagon assumes.

As the US diversifies its energy production portfolio, for example, by increasing renewable energy sources, it can further decrease dependence on Persian Gulf oil. Whether or not this mission is essential, operations to ensure access to oil are expensive,

\footnotetext{
http://citeseerx.ist.psu.edu/viewdoc/download;jsessionid=DD3F77E8166A096D9F1BB3B615199125?doi=1 0.1.1.186.7523\&rep=rep1\&type $=$ pdf.

81 Joshua Rovner, "After America: The Flow of Persian Gulf Oil in the Absence of US Military Force," in Glaser and Kelanic, eds., Crude Strategy, pp. 141-165: 160.

82 US Energy Information Agency, https://www.eia.gov/energyexplained/?page=us_energy_home.
} 
not to mention, fuel intensive. By one estimate, the annual incremental cost of US operations to protect against threats against Persian Gulf oil is about $\$ 5$ billion. ${ }^{83}$ By another estimate, at a minimum the US spends about $\$ 81$ billion annually defending the global oil supply. 84

\section{National Security Implications of Climate Change}

The US military, the intelligence community, and scholars of international security have been warning of the dangers posed by climate change for several decades. The US military and intelligence community tend to cluster the national security implications of global warming induced climate change into two overlapping areas. The first is how climate change will affect US installations and military operations, including how responding to climate disasters will stress military operations and potentially detract from other military missions. Second, how climate change poses political and national security threats, up to and including war. ${ }^{85}$

The military has long emphasized how climate change challenges military systems, operations, and infrastructure. For instance, in May 1990, Terry P. Kelly produced a paper for the Naval War College, "Global Climate Change Implications for the United States Navy" emphasizing threats to Navy "naval operations, facilities, and systems" in coming decades. The analysis focuses its recommendations on monitoring and adapting to climate change. ${ }^{86}$ More recently, the DOD offered a "Climate Change Adaptation Roadmap" in 2014 that stressed the necessity of preparing for and adapting to climate change. ${ }^{87}$ In early 2018 , the DOD reported that about half of their installations had already experienced climate change related effects. ${ }^{88} \mathrm{~A}$ year later, the DOD reported that the US military is already experiencing the effects of global warming at dozens of installations. ${ }^{89}$ These include recurrent flooding (53 installations), drought (43 installations), wildfires (36 installations), and

\footnotetext{
${ }^{83}$ Eugene Gholz, "U.S. Spending on Its Military Commitments to the Persian Gulf," in Charles L. Glaser and Rosemary A. Kelanic, eds., Crude Strategy: Rethinking the U.S. Military Commitment to Defend Persian Gulf Oil (Washington, DC: Georgetown University Press, 2016), pp. 167-195.

${ }^{84}$ Securing America's Future Energy, "The Military Cost of Defending the Global Oil Supply," 21 September, 2018, http://secureenergy.org/wp-content/uploads/2018/09/Military-Cost-of-Defending-the-Global-OilSupply.-Sep.-18.-2018.pdf.

85 For instance, see the US National Intelligence Council, "Implications for U.S. National Security of Anticipated Climate Change," 21 September 2016.

86 Terry P. Kelly, "Global Climate Change Implications for the United States Navy" Naval War College, May 1990. https://documents.theblackvault.com/documents/weather/climatechange/globalclimatechangenavy.pdf.

87 Department of Defense, "2014 Climate Change Adaptation Roadmap," https://www.acq.osd.mil/eie/Downloads/CCARprint wForward e.pdf.

88 Office of the Undersecretary of Defense for Acquisition, Technology and Logistics, "Department of Defense, Climate-Related Risk to DOD Infrastructure Initial Vulnerability Survey (SLVAS) Assessment Report," (January 2018). https://climateandsecurity.files.wordpress.com/2018/01/tab-b-slvas-report-1-242018.pdf.

${ }^{89}$ Department of Defense, "Report on the Effects of a Changing Climate to the Department of Defense," Office of the Undersecretary of Defense for Acquisition and Sustainment, January 2019.

https://climateandsecurity.files.wordpress.com/2019/01/sec 335 ndaareport effects of a changing climate to dod.pdf.
} 
desertification ( 6 installations). Vulnerability will only increase over the next twenty years unless the world begins to dramatically reduce all greenhouse gas emissions and sequester carbon dioxide..$^{90}$

The most urgent threat to military infrastructure is that rising sea levels and major storms will inundate coastal infrastructure and limit the use of naval bases..$^{91}$ Melting permafrost in the Arctic threatens the physical stability of the US military facilities in the Arctic. Keesler Air Force Base is regularly flooding. The National Climate Assessment released in late 2018 highlighted the US Naval Base at Norfolk Virginia as particularly vulnerable. Hurricane Michael destroyed much of Tyndall Air Force Base in October 2018 and Offutt Air Force Base in Nebraska, suffered major flooding in March 2019.

Figure 15. US Military Assets with Climate-Related Vulnerabilities. ${ }^{92}$

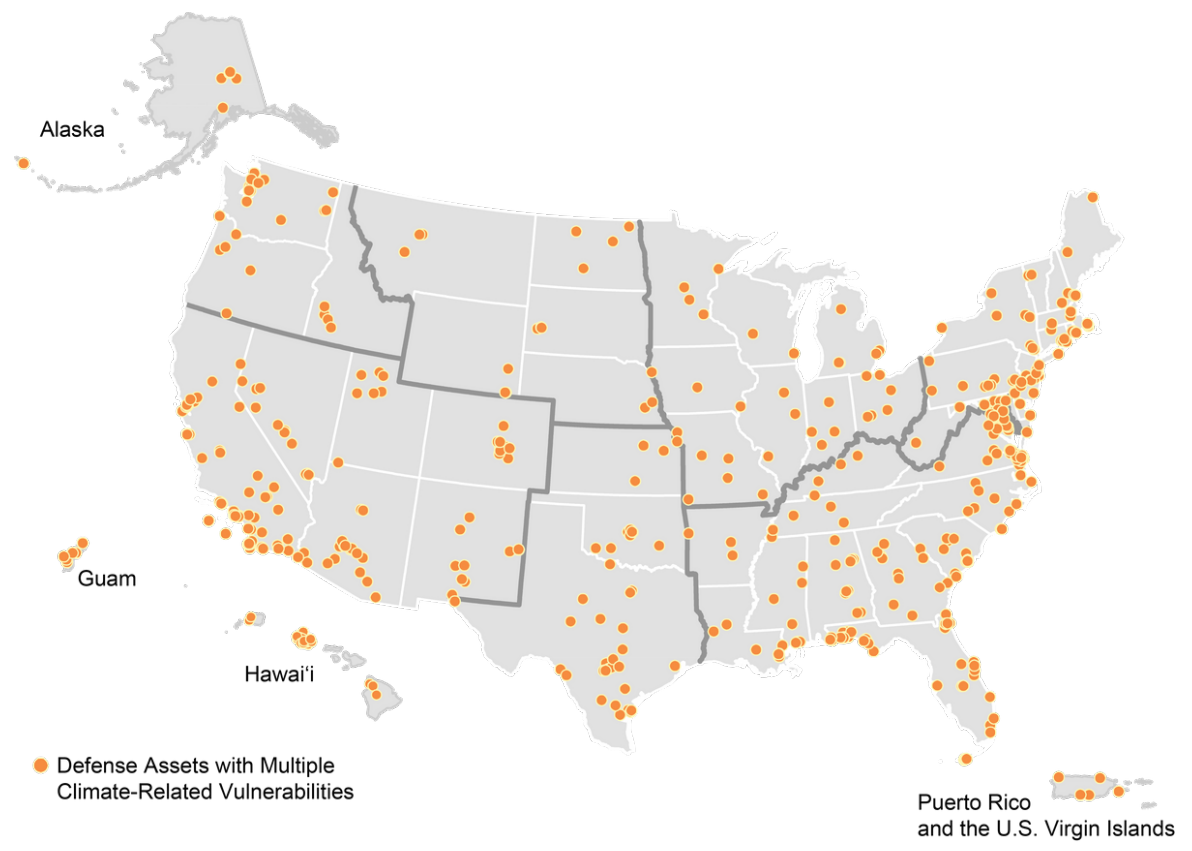

The Pentagon's response to the infrastructural and operational challenges of climate change has been to urge military preparations. These include potentially moving or closing military bases and developing training and equipment to operate in hotter and wetter or drier climates to meet climate change related threats to operations and resiliency.

In addition to the concern that a decline in access to oil would hurt the US and the global economy, the DOD has long been concerned that the US military itself, by requiring

\footnotetext{
${ }^{90}$ Department of Defense, "Report on the Effects of a Changing Climate to the Department of Defense," p. 5. Thawing permafrost is already occurring at Fort Greeley, Alaska.

${ }^{91}$ See U.S. Navy “Climate Change Roadmap," April 2010, Department of the Navy, https://www.navy.mil/navydata/documents/ccr.pdf.

92 Source: Figure 1.9. United States Global Change Research Program, Fourth National Climate Assessment: Volume II Impacts, Risks and Adaptation in the United States, (2018) https://nca2018.globalchange.gov/.
} 
enormous quantities of fuel for its operations, is too dependent on oil. Specifically, high fuel consumption rates during war-for weapons, equipment, and heating and cooling tentsincrease the need to transport fuel to conflict zones, which is itself a vulnerability and a loss of efficiency. Further, fuel has to be protected in transit and is vulnerable to disruptions in supply.

For example, during the US occupation of Afghanistan, US and NATO forces were dependent on the transit of fuel through Pakistan. Importing fuel into Afghanistan through Pakistan-where it comprised between 30 and 80 percent of each convoy-made the tankers vulnerable to attack. Between 2008 and 2014, convoys were attacked en route through Pakistan to NATO bases in Afghanistan 485 times, causing 167 deaths and 450 injuries. As the then Secretary of the Navy Ray Mabus said, "Fossil fuel is the No. 1 thing we import to Afghanistan and getting that fuel is keeping the troops doing what they were sent there to do, to fight or engage the local people."93 Further, tanker convoys through Pakistan were disrupted from late 2011 to early 2012 after the US inadvertently killed Pakistani troops and Pakistan halted those convoys for several months.

\section{Figure 16. Attacks on NATO Supply Convoys Through Pakistan, 2008 to $2014^{94}$}

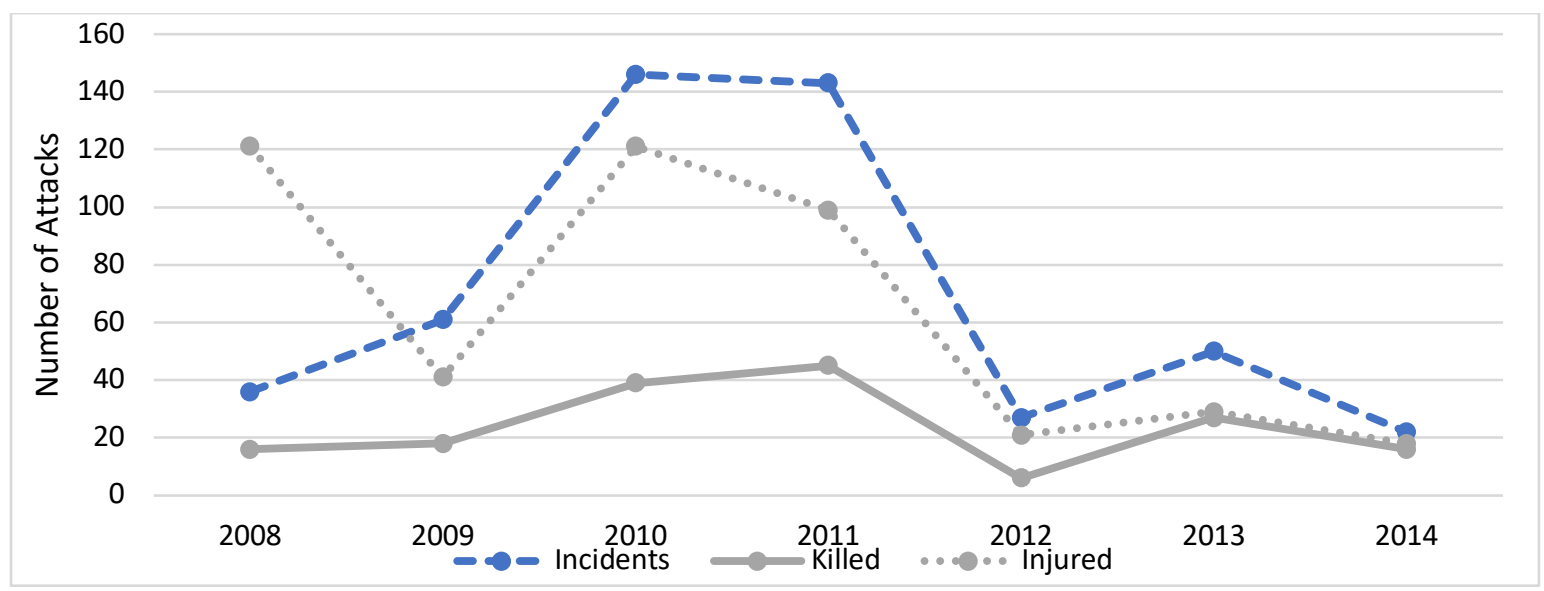

In 2003, then Marine Corp General John Mattis said that the US had to be "unleashed from the tether of fuel." In 2011, when asked by Congress member Adam Smith during Armed Services Committee Hearings, Mattis elaborated.

On the fuel, it is a significant Achilles heel for us when you have to haul the amounts of fuel that we have to haul around the battlefield for the generators and for the vehicles. We are working with DARPA [Defense Advanced Research Projects Agency], we are working with a number of civilian organizations to try and find solutions. There are efforts under way to make more expeditionary bases which would actually generate

\footnotetext{
${ }^{93}$ Elisabeth Rosenthal, "U.S. Military Orders Less Dependence on Fossil Fuels," The New York Times, 4 October 2010, https://www.nytimes.com/2010/10/05/science/earth/05fossil.html.

${ }^{94}$ Source of data: Pak Institute for Peace Studies, annual Pakistan Security Report, https://www.pakpips.com/publications\#1512730923805-d52fde57-07fa.
} 
some of their own energy requirements using, for example, solar power. In many of these places, there is a lot of sunshine. If we can get expeditionary capability to capture that and then basically recharge our batteries. I mean, it is an amazingly complex effort to maintain the fuel lines. And it also gives the enemy an ability to choose the time and place of attacking us. We are engaged with Science and Technology, we are engaged with DARPA, and we are looking at very pragmatic ways of doing this. We are also looking at what we can do to actually change how we distribute fuel, to reduce the enemy's opportunities to come after us. ${ }^{95}$

The Pentagon's response to concerns about fuel use has been to track fuel consumption, and to find ways to decrease consumption of fossil fuels through conservation and increased investment in renewable energy. The military efforts to reduce dependency have included reducing energy used at military installations and educating soldiers about the need to minimize idling vehicles-from Humvees to tanks to jets.

For example, in 2009, the newly created Marine Corps Expeditionary Energy Office began to collect data on Marine Corp energy usage from bulk distribution to the unit level. ${ }^{96}$ The Marines have gone quickly from analysis to action. In 2009, the Marines made their first study of fuel use in Afghanistan and in the following year the Marine Corps sent solar panels and chargers to their forces there. ${ }^{97} \mathrm{~A}$ few months later, the solar panels deployed in the Ground Renewable Expeditionary Energy System (Greens) had reportedly cut generator fuel consumption by nearly 90 percent, from 20 to 2.5 gallons per day. ${ }^{98}$ In 2010, the DOD established a Senior Sustainability Council. All of this work on efficiency has been accelerated and would not only save money, the military emphasizes, but also increase the resilience of the armed forces. ${ }^{99}$

In addition, the Pentagon uses other fuels and has continued to diversify its energy supplies. The US military relies on nuclear power for some important uses-most notably to power its fleet of 11 aircraft carriers. It is possible to substitute some alternative fuels for military applications and research on using bio-fuel in military vehicles, including jets.

The Pentagon has increased its use of renewable energy since 2009. The military has made a massive investment in solar generation and other renewable energy, doubling

\footnotetext{
95 Mattis at the Committee on Armed Services, Hearing on National Defense Authorization Act for Fiscal Year 2012, 3 March 2011, https://www.govinfo.gov/content/pkg/CHRG-112hhrg65114/html/CHRG112hhrg65114.htm.

${ }^{96}$ See Marine Corps, “United States Marine Corps Energy Expeditionary Strategy and Implementation Plan: Bases to Battlefields," 2010, https://www.hqmc.marines.mil/Portals/160/Docs/USMC\%20Expeditionary\%20Energy\%20Strategy\%20\% 20Implementation\%20Planning\%20Guidance.pdf.

${ }^{97}$ Suzanne Goldenberg, "US Marines in Afghanistan Launch First Energy Efficiency Audit in War Zone," The Guardian, 13 August 2009, https://www.theguardian.com/environment/2009/aug/13/us-marinesafghanistan-fuel-efficiency.

${ }^{98}$ Spencer Ackerman, "Afghanistan's Green Marines Cut Fuel Use by 90 Percent," Wired, 13 January 2011, https://www.wired.com/2011/01/afghanistans-green-marines-cut-fuel-use-by-90-percent/.

99 Office of the Assistant Secretary of Defense, Department of Defense Annual Energy Management and Resilience Report (AEMRR), https://www.acq.osd.mil/eie/Downloads/IE/FY\%202017\%20AEMR.pdf.
} 
renewable power generation between 2011 and 2015. ${ }^{100}$ But so far, switching to renewable sources has yielded the savings in emissions offsets less of than 1 percent of US DOD Greenhouse Gas emissions. ${ }^{101}$ Taken together, these efforts have borne fruit; the military has significantly reduced fuel use-even while waging war in Afghanistan, Iraq, and Syriaand there is enormous scope for reducing emissions even further. In 2017, the military's push to reduce energy consumption ran into politics when the Trump administration decided to deny climate change. The Pentagon was put in an awkward position; a headline in Fortune magazine framed the issue nicely: "The Military is Getting Greener, but That Clashes with Trump's Promises."102

The other operational concern is the threat climate change poses to the military's capacity to perform its core missions. National security officials anticipating a growing role supporting civil authorities in disaster relief missions are concerned that natural disasters, made worse as a consequence of climate change, will stress the operational capacities of the US military. As sea levels rise, critical civilian infrastructure will be at risk. In September 2016, President Obama issued a National Security Memorandum that said, "Climate change and associated impacts on US military and other national security-related missions and operations could adversely affect readiness, negatively affect military facilities and training, increase demands for Federal support to non-federal civil authorities, and increase response."103

\section{Fear of Climate Chaos and War}

The military has become increasingly concerned that climate change poses a threat to international security. ${ }^{104}$ In the 2015 National Security Strategy, the Obama Administration said, "Climate change is an urgent and growing threat to our national security, contributing to increased natural disasters, refugee flows, and conflicts over basic resources like food and water. The present day effects of climate change are being felt from the Arctic to the Midwest. Increased sea levels and storm surges threaten coastal regions, infrastructure,

\footnotetext{
100 Timothy Garder, “U.S. Military Marches on Toward Green Energy, Despite Trump," Reuters, 1 March 2017, https://www.reuters.com/article/us-usa-military-green-energy-insight/u-s-military-marches-forward-ongreen-energy-despite-trump-idUSKBN1683BL. Also see Reuters, "Military Getting Greener," http://fingfx.thomsonreuters.com/gfx/rngs/USA-TRUMP-ENERGY-MILITARY/0100400G00X/index.html. ${ }^{101}$ Annual Data on Energy from https://www.energy.gov/eere/femp/federal-facility-annual-energy-reportsand-performance.

102 Associated Press, “The Military is Getting Greener, but That Clashes with Trump’s Promises.” Fortune, 14 January 2017. http://fortune.com/2017/01/14/military-oil-trump-green-power/. ${ }_{103}$ Memorandum for the Heads of Executive Departments and Agencies, Climate Change and National Security, 21 September 2016, https://www.justice.gov/opa/file/895016/download.

${ }^{104}$ For instance, see Kurt M. Campbell, et al, "The Age of Consequences: The Foreign Policy and National Security Implications of Global Climate Change," Center for Strategic \& International Studies and Center for New American Security, November 2007, https://csis-prod.s3.amazonaws.com/s3fspublic/legacy files/files/media/csis/pubs/071105 ageofconsequences.pdf. Center for Naval Analysis, National Security and the Threat of Climate Change, Center for Naval Analysis 2007. https://www.cna.org/cna files/pdf/national\%20security\%20and\%20the\%20threat\%20of\%20climate\%20c hange.pdf.
} 
and property. In turn, the global economy suffers, compounding the growing costs of preparing and restoring infrastructure."105

In the most recent National Security Strategy, the Trump administration ignored climate change. In response, more than 100 members of Congress wrote to the President in January 2018 to underscore the risks and to urge the President to include climate change in the National Security Strategy. ${ }^{106}$ And at the same time, Retired Admiral James Stavridis argued that climate change was arguably the most pressing national security challenge the US faced. Stavridis said, "What makes climate change so pernicious is that while the effects will only become catastrophic far down the road, the only opportunity to fix the problem rests in the present. In other words, waiting 'to be sure climate change is real' condemns us to a highly insecure future if we make the wrong bet. We are in danger of missing not only the vast forest of looming climate change, but the ability to see some of the specific trees that will cause us the most problems."107

The military is concerned that climate change will lead to a more chaotic and dangerous world. They are concerned, for instance, that the Arctic Sea is now open, leading to questions about the need to patrol it. ${ }^{108}$ National security analysts sometimes suggest that drought in Syria from 2007 to 2010, and the subsequent mass migration to cities, created the conditions that contributed to the emergence of the civil war there in 2011.

Indeed, some strategists paint nightmare scenarios where climate change leads to armed conflict—such as when crop failures produce famine and drought lead to conflicts over water and other natural resources. The White House said in 2016 that "The national security implications of climate change impacts are far-reaching, as they may exacerbate existing stressors, contributing to poverty, environmental degradation, and political instability, providing enabling environments for terrorist activity abroad. For example, the impacts of climate change on key economic sectors, such as agriculture and water, can have profound effects on food security, posing threats to overall stability." 109 Similarly, in September 2016, the National Intelligence Council listed a range of concerns from increased migration, to food shortages, to greater conflict and war caused by shortages of fresh water and access to arable land.110

105 White House, "National Security Strategy," February 2015, p. 12, https://obamawhitehouse.archives.gov/sites/default/files/docs/2015_national_security_strategy_2.pdf. 106 The letter is found at https://langevin.house.gov/sites/langevin.house.gov/files/documents/01-1118 Langevin Stefanik Letter to POTUS Climate Change National Security Strategy.pdf. 107 James Stavridis, "America's Most Pressing Threat? Climate Change," Bloomberg Opinion, 11 January 2018, https://www.bloomberg.com/opinion/articles/2018-01-11/america-s-no-1-enemy-climate-change. 108 US Navy Task Force on Climate Change, “The United States Navy Arctic Roadmap, 2014-2030," February 2014, http://navysustainability.dodlive.mil/files/2014/02/USN-Arctic-Roadmap-2014.pdf. 109 White House, "Findings from Select Federal Reports: The National Security Implications of Climate Change" May 2015, p. 3.

${ }^{110}$ National Intelligence Council, "Implications for US National Security of Anticipated Climate Change," NIC WP2016-01, 21 September 2016. https://www.dni.gov/files/documents/Newsroom/Reports\%20and\%20Pubs/Implications for US National Security of Anticipated Climate Change.pdf. 
The intelligence community has kept its eyes on climate change even as President Trump denies that global warming is a problem. In January 2019, Daniel R. Coats, Director of National Intelligence told the Senate Select Committee on Intelligence that, "Global environmental and ecological degradation, as well as climate change, are likely to fuel competition for resources, economic distress, and social discontent through 2019 and beyond. Climate hazards such as extreme weather, higher temperatures, droughts, floods, wildfires, storms, sea level rise, soil degradation, and acidifying oceans are intensifying, threatening infrastructure, health, and water and food security. Irreversible damage to ecosystems and habitats will undermine the economic benefits they provide, worsened by air, soil, water, and marine pollution."111

It is true that social and economic stressors, such mass migration and tensions over access to fresh water, that might lead to or exacerbate conflicts will increase as temperatures increase because of climate change.

But it is not inevitable that climate change will lead to war. ${ }^{112}$ Humans could use existing institutions or develop mechanisms to cooperate in the face of climate change stressors. And they could act now to reduce the most dangerous and disruptive effects of climate change by reducing their emissions of Carbon Dioxide, Methane, Nitrous Oxide and other greenhouse gases, and by pulling Carbon Dioxide out of the atmosphere by sequestering carbon in forests and soil. Prevention will ultimately be less conflictual than responding after the fact.

Part of the Pentagon's response to concerns about climate change has been to create new organizations within the DOD and to study the issue. ${ }^{113}$ For instance, the Navy created the "Task Force Climate Change" (TFCC) in 2009. The other response has been to repair naval and air bases after climate change related events damage those installations. Further, the military is preparing for conflict in the newly open Arctic and preparing other climate conflict responses. ${ }^{114}$

However, the Pentagon does not acknowledge that its own fuel use is a substantial contributor to global greenhouse gas emissions. Nor has the DOD acknowledged that reductions in Pentagon fuel use, or indeed overall US petroleum consumption, are a potentially significant way to reduce the risks of climate caused operational vulnerabilities and national security risks. But the Pentagon could make the same connections that Congressman Henry Waxman made more than two decades ago. In May 1998, Waxman

\footnotetext{
111 Daniel R. Coats, "Worldwide Threat Assessment of the US Intelligence Community, Statement for the Record," Senate Select Committee on Intelligence" 29 January 2019. https://www.dni.gov/files/ODNI/documents/2019-ATA-SFR---SSCI.pdf, p. 23.

112 See Katharine J. Mach, et al, "Climate as a Risk Factor for Armed Conflict," Nature, vol. 571, 11 July 2019, pp. 193-197.

113 On the other hand, a 2017 GAO report suggested that the US military had not consistently taken the likely budgetary impacts of climate change into account. Government Accountability Office, "Climate Change Adaptation: DOD Needs to Better Incorporate Adaptation into its Planning and Collaboration at Overseas Installations," November 2017, https://www.gao.gov/assets/690/688323.pdf. 114
} 
said, "the Kyoto Protocol will improve the national security of the United States by reducing the risk of catastrophic climate change, which would create upheaval and unrest throughout the world, including the potential for millions of environmental refugees." Waxman also argued that "measures to implement the Kyoto Protocol can improve our security by reducing our dependence on imported oil through improved energy efficiency and increased reliance on domestic renewable energy resources."115

\section{Conclusion}

Even as the US has begun to scale back the size of its military presence in Afghanistan, Iraq, and Syria, the US is engaged in a massive build-up of its military capacities. The US military budget is larger than it has ever been since the end of the Cold War even as the United States has reduced its footprint in Afghanistan and Syria in 2019 by withdrawals.

The post-9/11 war missions and the global military posture have not been systematically reevaluated. Despite recent withdrawals from Syria, absent a strategy, the US may continue policing the Persian Gulf even as it turns to what it perceives is an emerging threat from China and an increasing military presence in Africa. All of these activities demand fuel consumption and are hence greenhouse gas emission intensive. Further, despite the fact the US military acknowledges that it has excess capacity, there has not been a push for base realignment and closure. ${ }^{116}$

The US has an important public policy decision to make. Do we continue to orient our foreign policy and military force posture toward ensuring access to fossil fuels? Or does the US dramatically reduce the use of fossil fuels, including the military's own dependency, and thus reduce the perceived need to preserve access to oil resources? The DOD has reduced some of its fuel consumption: how much more could it reduce consumption?

Reductions in military fuel use would be beneficial in four ways. First, if the US were to decrease its dependence on oil, the US could reduce the political and fuel resources it uses to defend access to oil. If the US further reduced its imports of oil from the Persian Gulf, including fuel used by the military to protect those imports, it could then reevaluate the size of the US military presence in the region and reevaluate its relationship with Saudi Arabia and other allies in the region. The US would reap political and security benefits, including reducing the dependence of troops in the field on oil and decreasing dependence on oil and those who provide it.

Second, by dramatically decreasing fossil fuel consumption, the US military would reduce overall US greenhouse gas emissions and perhaps promote carbon sequestration (taking carbon out of the atmosphere and fixing it in the soil and trees). There are many

\footnotetext{
115 Waxman, 20 May 1998. Congressional Record, House, vol. 144, part 7, Proceedings and Debates of the $105^{\text {th }}$ Congress, p. 9983.

${ }^{116}$ Leo Shane, "Plans for a New Base Closing Round May be Running Out of Time: Report," Military Times, 15 August 2019, https://www.militarytimes.com/news/pentagon-congress/2019/08/15/plans-for-a-newbase-closing-round-may-be-running-out-of-time-report/.
} 
ways to do this, from more modest measures such as increasing fuel economy and using alternative fuels, which the Pentagon has begun to do. Some base closures will be necessitated by climate change itself. More significant reductions in greenhouse gas emissions will be gained by restructuring the US military posture, including reducing US military operations and installations worldwide, and closing bases in the US. Base closures could also lead to significant carbon sequestration if those public lands are reforested. See Appendix 2 for modest suggestions for Congressional action.

Third, by reducing the use of greenhouse gas-emitting fuels (coupled with emission reductions in other sectors) the Pentagon would decrease its contribution to the associated climate change threats to national security. Indeed, the Pentagon could play a major role in reducing the worst effects of climate change, and any potential security consequences of global warming, rather than reacting to climate change emergencies or cleaning up after those effects have occurred.

Fourth, as a consequence of spending less money on fuel and operations to provide secure access to petroleum, the US could, in the long run, decrease US military spending and reorient its economy to more economically productive activities. Indeed, if the US military converted more of its energy consumption to renewable energy, this would stimulate the renewable energy industry in the US, with important economic benefits for the entire US economy. ${ }^{117}$

In sum, reducing Pentagon fossil fuel use could have enormous positive implications for the climate and the US economy. Moreover, if as Admiral Locklear and others suggest, climate change is a more certain national security threat than many others, the military might move beyond simply "consequence management" by preparing to react to climate related conflicts to conflict prevention by further reducing their fuel use and greenhouse gas emissions.

117 The author thanks Alexander Thompson for raising this point. 


\section{Appendix 1. Calculating US Military Greenhouse Gas Emissions}

Due to gaps in reporting and accounting by the DOD, it is impossible to provide a precise calculation of the total greenhouse gas emissions of the US military. The Pentagon does not release petroleum fuel consumption data and most US government accounting of US greenhouse gas emissions omit figures on how much the military and military industry contributes to US emissions. Further, as discussed above, emissions from international bunker fuels (for military aircraft and ships) and multilateral wars were excluded from national accounts in the Kyoto Protocol negotiations in 1998. The US does not appear to count most bunker fuels in its Greenhouse Gas Inventory national totals. ${ }^{118}$ While there is Department of Energy emissions data for the Department of Defense for FY2008, and FY2010-2018 there is no emissions data for the other years.

Absent a full Pentagon accounting of their fuel consumption and emissions by operation, there are various ways to estimate DOD greenhouse gas emissions in the post$9 / 11$ wars. To find the total war related emissions for the entire period of war, one needs data for the entire period. Then one could estimate, based on some criteria, the amount of total greenhouse gas emissions that are due to the post-9/11 wars.

One could base an estimate of total greenhouse gas emissions that should be attributed to the war on the proportion of the total military budget spent on Overseas Contingency Operations. In other words, one can use the average portion of the DOD budget spent on Overseas Contingency Operations as an approximate measure of energy use related to the war effort and assume that some portion of the base budget, and therefore base/non-war operations and installation energy use, is correlated to war related spending. The Overseas Contingency Operations budget for the major war zones accounted for an average of 17 percent of the entire DOD (top line) budget from FY2001 to 2018. But this rule of thumb would give an estimate of war related emissions that would be too low, since non-standard emissions account for such a high proportion of all DOD fuel use.

A better way to estimate total greenhouse gas emissions for Overseas Contingency Operations would be to focus on operational fuel consumption, defined in DOE parlance as non-standard fuel consumption. Between FY2010-2018, the Department of Energy attributed 63 percent of all DOD greenhouse gas emissions to non-standard operations. However, to assume that all non-standard fuel use was for the major wars would yield an estimate that is probably too high, since the DOD performs other, non-post-9/11 war related missions - such as exercises with its allies or in more recent years, operations on the Southern border of the United States. Table 3 reproduces the FY2018 Department of Energy Greenhouse Gas Inventory for the Department of Defense.

118 See US Environmental Protection Agency, Inventory of Greenhouse Gases and Sinks: 1990-2016, https://www.epa.gov/sites/production/files/2018-01/documents/2018 complete_report.pdf and US Environmental Protection Agency, Inventory of Greenhouse Gases and Sinks: 1990-2017, https://www.epa.gov/sites/production/files/2019-02/documents/us-ghg-inventory-2019-main-text.pdf. Also see Annex 3, Part A, Section 3.8 where the method is to "omit all international fuel transactions/deliveries" and "all land based fuels," https://www.epa.gov/sites/production/files/201902/documents/us-ghg-inventory-2019-annex-3-additional-source-or-sink-categories-part-a.pdf. 
Table 3. DOD Greenhouse Gas Inventory, FY2018 119

\begin{tabular}{|c|c|c|c|}
\hline \multirow[b]{2}{*}{ Scope and Category } & \multicolumn{3}{|c|}{ FY 2018} \\
\hline & $\begin{array}{l}\text { GHG Emissions from } \\
\text { Standard Operations } \\
\quad(\mathrm{MT} \text { CO2e) }\end{array}$ & $\begin{array}{l}\text { GHG Emissions } \\
\text { from Non-Standard } \\
\text { Operations* (Military } \\
\text { Operations, Law } \\
\text { Enforcement, and } \\
\text { Other) } \\
\text { (MT CO2e) }\end{array}$ & $\begin{array}{l}\text { Total Quantity } \\
\text { Emitted } \\
\text { Biogenic } \\
\text { (MT CO2e) }\end{array}$ \\
\hline Scope 1: On-Site Fuel Consumption at Federal Facilities & $5,403,108.4$ & 0.0 & $81,754.4$ \\
\hline $\begin{array}{l}\text { Scope 1: Mobile Emissions--Vehicles, Aircraft, Ships, and } \\
\text { Equipment }\end{array}$ & $1,159,348.4$ & $33,804,424.0$ & $10,194.2$ \\
\hline Scope 1: Mobile Emissions--Passenger Fleet Vehicles & $420,289.1$ & $71,354.2$ & $33,654.2$ \\
\hline $\begin{array}{l}\text { Scope 1: Fugitive Emissions--Fugitive Fluorinated Gases } \\
\text { and Other Fugitive Emissions }\end{array}$ & $328,777.1$ & $658,708.8$ & \\
\hline $\begin{array}{l}\text { Scope 1: Fugitive Emissions--On-site Wastewater } \\
\text { Treatment }\end{array}$ & $5,636.9$ & & $1,274.0$ \\
\hline $\begin{array}{l}\text { Scope 1: Fugitive Emissions--On-site Landfills and } \\
\text { Municipal Solid Waste Facilities }\end{array}$ & $155,535.8$ & & $41,231.3$ \\
\hline Scope 1: Manufacturing and Industrial Process Emissions & 0.0 & 0.0 & \\
\hline Subtotal Scope 1 & $7,472,695.6$ & $34,534,487.1$ & $168,108.2$ \\
\hline Scope 2: Purchased Electricity & $13,019,180.1$ & 0.0 & 0.0 \\
\hline Scope 2: Purchased Biomass Energy & $3,965.3$ & & $331,885.2$ \\
\hline Scope 2: Purchased Steam and Hot Water & $573,203.7$ & 0.0 & 0.0 \\
\hline Scope 2: Purchased Chilled Water & $2,300.8$ & 0.0 & 0.0 \\
\hline $\begin{array}{l}\text { Scope 2: Purchased Combined Heat and Power } \\
\text { Electricity, Steam \& Hot Water }\end{array}$ & 0.0 & 0.0 & 0.0 \\
\hline Subtotal Scope 2 & $13,598,650.0$ & 0.0 & $331,885.2$ \\
\hline Scope 2: Reductions from Renewable Energy Use & $-199,188.5$ & & 0.0 \\
\hline Subtotal Scope $1 \& 2$ & $20,872,157.1$ & $34,534,487.1$ & $499,993.3$ \\
\hline $\begin{array}{l}\text { *Non-Standard Operations are vehicles, vessels, aircraft a } \\
\text { combat support, combat service support, tactical or relief } \\
\text { emergency response, or spaceflight (including associated }\end{array}$ & $\begin{array}{l}\text { ler equipment used } \\
\text { ions, training for sucl } \\
\text { d-support equipmen }\end{array}$ & $\begin{array}{l}\text { ederal Government } \\
\text { erations, law enforce } \\
\text { on-Standard operati }\end{array}$ & $\begin{array}{l}\text { ncies in } \\
\text { also includes }\end{array}$ \\
\hline
\end{tabular}

Another, and arguably better, method would be to base estimates of greenhouse gas emissions during the major wars on the proportion of fuel use by Central Command and other war zones. In FY2014 (see figure 4), Central Command used about 24 percent of the total operational fuel consumption by the DOD. But because US post-9/11 counterterror operations are underway all over the world (in about 80-90 countries) the Central Command is not the only war zone in the global war on terror.

The estimate derived here is thus based on the assumption that the portion of all greenhouse gas emissions related to the Global War on Terror, in patrolling the Persian Gulf and Central Command Overseas Contingency Operations is about 35 percent of total greenhouse gas emissions for non-standard and standard operations.

\footnotetext{
${ }^{119}$ Department of Energy, https:/ctsedwweb.ee.doe.gov/Annual/Report/ComprehensiveGreenhouseGasGHGInventoriesByAgencyAndFiscalY ear.aspx.
} 
These methods assume that total emissions data is available. While data for standard and non-standard greenhouse gas emissions by US government department are available for FY2008, and FY2010-2018 on the Department of Energy website, there is no accounting of standard and non-standard emissions for other years. ${ }^{120}$ The emissions for other years were therefore estimated from calculations of fuel consumption for vehicle and equipment use for the period of FY1975 to FY2018 found in the Department of Energy fuel consumption data Comprehensive Annual Energy Data and Sustainability Annual Reports. ${ }^{121}$

Specifically, non-standard emissions were estimated, based on vehicle and equipment emissions for the missing years, and then the standard emissions were estimated in proportion to non-standard emissions. For example, a calculation of CO2e emissions for US DOD jet fuel consumption in 2017 is illustrated in Table 4. The calculation of $\mathrm{CO} 2$ equivalent emissions of jet fuel makes the following assumptions: each gallon of jet fuel produces $0.135 \mathrm{HHV}$ MMBtu/gallon. Using the standard emission factors for jet fuel- $\mathrm{CO} 2$ of $72.22 \mathrm{~kg} / \mathrm{MMBtu}$; for CH4 (methane) of $.003 \mathrm{~kg} / \mathrm{MMBtu}$; and for N2O (nitrous oxide) of $.0006 \mathrm{~kg} / \mathrm{MMBtu}$ - one can calculate the greenhouse gas, CO2 equivalent, emissions for a given quantity of jet fuel. ${ }^{122}$ The Global Warming Potential 100 year values are the EPA and Department of Energy assumptions of 25 for methane and 298 for Nitrous Oxide. ${ }^{123}$

Table 4. Calculating Greenhouse Gas Emissions for US Military Jet Fuel Consumption, FY2017.

\begin{tabular}{|l|r|r|}
\hline & Jet Fuel & Unit of Measure \\
\hline $\begin{array}{l}\text { Annual Consumption GHG Non-Standard } \\
\text { Operations }\end{array}$ & $2,915,738.50$ & thousand gallons \\
\hline Total Energy Consumed & $393,624,693.30$ & \\
\hline Cost & $\$ 6,681,061.20$ & \\
\hline Unit Cost & $\$ 2.29$ & \\
\hline Anthropogenic CO2 Emission Factor & 72.2 & $\mathrm{~kg} \mathrm{CO2} / \mathrm{MMBtu}$ \\
\hline CH4 Emission Factor & 0.003 & $\mathrm{~kg} \mathrm{CH} 4 / \mathrm{MMBtu}$ \\
\hline N2O Emission Factor & 0.0006 & $\mathrm{~kg} \mathrm{N2O} / \mathrm{MMBtu}$ \\
\hline
\end{tabular}

\footnotetext{
${ }^{120}$ See Department of Energy Comprehensive Annual Energy Data and Sustainability Performance, https://ctsedwweb.ee.doe.gov/Annual/Report/Report.aspx.

121 Department of Energy, "Comprehensive Annual Energy Data and Sustainability Performance," Annual Reports, http://ctsedwweb.ee.doe.gov/Annual/Report/ComprehensiveGreenhouseGasGHGInventoriesByAgencyAndF iscalYear.aspx. Data as of 1 June 2018. Energy consumption from the Department of Energy, http://ctsedwweb.ee.doe.gov/Annual/Report/HistoricalFederalEnergyConsumptionDataByAgencyAndEnerg yTypeFY1975ToPresent.aspx.

122 CO2, Methane and Nitrous Oxide emission factors are from Office of Energy \& Renewable Energy, Federal Comprehensive Annual Energy and reporting Requirements, https://www.energy.gov/eere/femp/federalfacility-consolidated-annual-reporting-requirements.

123 GWP emissions coefficients, https://www.eia.gov/environment/emissions/co2 vol mass.php.
} 


\begin{tabular}{|l|r|r|}
\hline Total Quantity Emitted Anthropogenic & & $\mathrm{kg}$ \\
\hline CO2 & $28,427,575,352.60$ & $\mathrm{~kg}$ \\
\hline Total Quantity Emitted CH4 & $1,180,874.10$ & $\mathrm{~kg}$ \\
\hline Total Quantity Emitted N2O & $236,174.80$ & $\mathrm{CO2e}$ \\
\hline GWP Factor for CO2 & 1 & $\mathrm{CO2e}$ \\
\hline GWP Factor for CH4 & 25 & CO2e \\
\hline GWP Factor for N2O & 298 & $\mathrm{~kg} \mathrm{CO2e}$ \\
\hline Total Quantity Emitted (CO2e) & $28,527,477,299.80$ & MT CO2e \\
\hline Total Quantity Emitted (MT CO2e) & $28,527,477.30$ & \\
\hline
\end{tabular}

DOE fuel consumption data for the DOD were used to calculate annual emissions for DOD vehicle and equipment caused greenhouse gas emissions for each fuel type-gasoline, diesel, LPG/propane, aviation gas, jet fuel, and Navy special fuel—based on fuel energy consumption rates for the years where there is no published Department of Energy emissions data. ${ }^{124}$ Assuming that non-standard emissions from vehicle fuel consumption were very close to the total non-standard fuel consumption for the DOD, standard emissions were estimated for each year. During the years where there is Department of Energy data for all DOD emissions (FY2010-2018), non-standard emissions were on average 63 percent of total emissions. Standard emissions were estimated for FY19752007 and FY2009 assuming that the ratios were about the same through the entire period. The results are shown in Table 5 and graphed in Figure 8, above.

Table 5. Estimated Annual DOD Greenhouse Gas Emissions of the, FY1975-2018 125

\begin{tabular}{|c|c|c|c|}
\cline { 1 - 3 } Fiscal Year & $\begin{array}{c}\text { Standard Emissions, } \\
\text { Millions of Metric Tons }\end{array}$ & $\begin{array}{c}\text { Non-Standard Emissions, } \\
\text { Millions of Metric Tons }\end{array}$ & $\begin{array}{c}\text { Total CO2e Emissions, } \\
\text { Millions of Metric Tons }\end{array}$ \\
\hline \hline 1975 & 40 & 69 & 109 \\
\hline \hline 1976 & 35 & 59 & 93 \\
\hline \hline 1977 & 35 & 60 & 95 \\
\hline \hline 1978 & 34 & 58 & 92 \\
\hline \hline 1979 & 35 & 60 & 95 \\
\hline \hline 1980 & 36 & 61 & 97 \\
\hline \hline 1981 & 39 & 66 & 104 \\
\hline 1982 & 39 & 67 & 106 \\
\hline 1983 & 39 & 67 & 109 \\
\hline 1984 & 40 & 68 & \\
\hline
\end{tabular}

${ }^{124}$ Because the heat content and greenhouse gas emission of the various products of crude oil (e.g. diesel and jet fuel) are different, calculations must use the specific heat content and emissions profiles for each fuel. The average heat content of crude oil is $5.80 \mathrm{mmbtu}$ per barrel (EPA 2018). The average carbon coefficient of crude oil is $20.31 \mathrm{~kg}$ carbon per mmbtu (EPA 2018). The fraction oxidized is 100 percent. $5.80 \mathrm{mmbtu} / \mathrm{barrel}$ $\times 20.31 \mathrm{~kg} \mathrm{C} / \mathrm{mmbtu} \times 44 \mathrm{~kg} \mathrm{CO}_{2} / 12 \mathrm{~kg} \mathrm{C} \times 1$ metric ton/1,000 kg $=0.43$ metric tons $\mathrm{CO}_{2} /$ barrel.

${ }^{125}$ Calculated from Department of Energy fuel consumption data rounded to the nearest metric ton. Figures in italics, for FY2008 and FY2010-2018, are the Department of Energy reported emissions figures. 


\begin{tabular}{|c|c|c|c|}
\hline 1985 & 39 & 67 & 106 \\
\hline 1986 & 39 & 66 & 105 \\
\hline 1987 & 40 & 69 & 109 \\
\hline 1988 & 35 & 60 & 95 \\
\hline 1989 & 40 & 68 & 109 \\
\hline 1990 & 39 & 66 & 105 \\
\hline 1991 & 41 & 69 & 110 \\
\hline 1992 & 32 & 55 & 88 \\
\hline 1993 & 32 & 55 & 87 \\
\hline 1994 & 30 & 51 & 80 \\
\hline 1995 & 28 & 48 & 76 \\
\hline 1996 & 27 & 46 & 74 \\
\hline 1997 & 27 & 45 & 72 \\
\hline 1998 & 25 & 43 & 69 \\
\hline 1999 & 25 & 42 & 66 \\
\hline 2000 & 23 & 39 & 62 \\
\hline 2001 & 23 & 40 & 63 \\
\hline 2002 & 26 & 44 & 70 \\
\hline 2003 & 29 & 49 & 78 \\
\hline 2004 & 32 & 54 & 85 \\
\hline 2005 & 31 & 52 & 83 \\
\hline 2006 & 27 & 46 & 73 \\
\hline 2007 & 28 & 48 & 76 \\
\hline 2008 & 27 & 50 & 77 \\
\hline 2009 & 28 & 48 & 77 \\
\hline 2010 & 27 & 50 & 77 \\
\hline 2011 & 26 & 49 & 75 \\
\hline 2012 & 25 & 45 & 70 \\
\hline 2013 & 24 & 39 & 64 \\
\hline 2014 & 24 & 38 & 62 \\
\hline 2015 & 24 & 39 & 63 \\
\hline 2016 & 22 & 37 & 59 \\
\hline 2017 & 22 & 37 & 59 \\
\hline 2018 & 21 & 35 & 56 \\
\hline Total & 1,361 & 2,324 & 3,685 \\
\hline
\end{tabular}

These estimates of US military greenhouse gas emissions are conservative for four reasons. First, the impact of methane and nitrous oxide gases, their Global Warming Potentials (GWP) is not the same as C02 but significantly higher. When calculating the total 
greenhouse gas emissions, these other greenhouse gases are scaled into an equivalent relation to carbon dioxide, which has, by definition, a GWP of 1. The Department of Energy and the EPA use the US EPA 100 year Global Warming Potentials which scales the GWP of methane, CH4, at 25 and nitrous oxide, N20, at 298 over 100 years. ${ }^{126}$ The Intergovernmental Panel on Climate Change Fifth Assessment Report uses a GWP of 34 for Methane's CO2 equivalent.127 If the IPCC global warming potentials were used, estimates of US DOD greenhouse gas emissions would be higher. Further, I have also not calculated the emissions from fluorinated gases from US vehicles and equipment.

Second, recall that jet fuel is the major source of vehicle non-standard military greenhouse gas emissions. $\mathrm{CO} 2$ is the major product of jet fuel consumption but jet fuel combustion emissions at high altitude also contain water vapor, a global warming gas, which itself causes the formation of cirrus clouds. The DOD also puts additives in its jet fuels to ensure that they perform according to military requirements. For instance, because military jets fly at much higher altitudes than commercial jets, they use additives to ensure that the fuel lines do not freeze. Any emissions from those additives and warming from water vapor are not counted. Scientists agree that even though CO2 is the major product of jet fuel consumption, the impact of these other greenhouse gases is significant. While the Department of Energy figures and the calculations here include nitrous oxide and methane, it is possible that the additional effects of additives for jet fuel combustion, which are not included in these calculations, is significant. "Non-CO2 impacts cannot be ignored as they potentially represent approximately $60 \%$ of total climate impacts that are important in the shorter term (excluding cloudiness impacts)."128 In sum, this means that the impact of military aviation emissions when all greenhouse gases are included may be much higher

\footnotetext{
${ }_{126}$ PFCs, HFCs, NF3, and SF6 have global warming potentials that range from 7,390 to 22,800. While the global warming effects of methane, nitrous oxide, and water vapor are well understood, when they are emitted during jet fuel combustion at high altitudes the effects are not as well understood as the effects of C02. See the US Environmental Protection Agency, "Emissions of Flourinated Gases," https://www.epa.gov/ghgemissions/overview-greenhouse-gases\#f-gases and "Understanding Global Warming Potentials," https://www.epa.gov/ghgemissions/understanding-global-warming-potentials. The Department of Energy uses the EPA GWP factors. See their Energy Management Data Report.

https://www.energy.gov/eere/femp/downloads/annual-energy-management-data-report and Council on Environmental Quality, "Federal Greenhouse Gas Accounting and Reporting Guidance," 17 January 2016, p. 4. https://www.sustainability.gov/pdfs/federal ghg\%20accounting_reporting-guidance.pdf.

${ }^{127}$ IPCC Second Assessment Report 100 GWP See the IPCC Fifth Assessment Report, Climate Change 2014: Synthesis Report. Contribution of Working Groups I, II and III to the Fifth Assessment Report of the Intergovernmental Panel on Climate Change [Core Writing Team, R.K. Pachauri and L.A. Meyer (eds.)]. (IPCC, Geneva, Switzerland, 2014). https://www.ipcc.ch/site/assets/uploads/2018/02/SYR AR5 FINAL full.pdf.

128 European Environment Agency, European Union Aviation Safety Agency, Eurocontrol, "European Aviation Environment Report, 2019" January 2019, p. 88.

https://www.easa.europa.eu/eaer/system/files/usr_uploaded/219473_EASA_EAER_2019_WEB_LOWRES.pdf. Also see Martin Cames, Jakob Graichen, Anne Siemons, and Vanessa Cook, "Emission Reduction Targets for International Aviation and Shipping," Policy Department A: Economic and Scientific Policy, European Union, November 2015, pp. 13-14. http://www.europarl.europa.eu/RegData/etudes/STUD/2015/569964/IPOL_STU(2015)569964_EN.pdf.
} 
than those estimated here. Jet contrails, leading to the creation of cirrus clouds, is a significant contributor to global warming. ${ }^{129}$

Third, the focus is on the major emissions of the DOD. Specifically not included are estimates for what are called Scope 3 emissions, from, for instance, employee air and ground business travel, wastewater treatment, and solid waste disposal. For example, US DOD Scope 3 emissions in 2008 were 7.6 million MT CO2e, and in 2016, 7 million MT CO2e. Nor are biogenic emissions included. In FY2017 and FY2018, for example, US DOD biogenic emissions were .57 million MT CO2e and .49 million MT of CO2e.

Fourth, there are some sources of DOD facilities energy for which the source fuel is unclear. Table 6 shows Department of Energy data for DOD site delivered energy use in FY2018. The DOD acquires electricity and purchases steam for facilities from external power suppliers, but the DOE does not provide detail about the fuel used to produce that electricity. The source of electricity or steam in those categories could be nuclear power, which would have no greenhouse gas emissions, or coal, which could have a significant greenhouse gas footprint.

Table 6. Department of Defense Site Delivered Energy Use and Costs, FY2018 130

\begin{tabular}{|c|c|c|c|c|}
\hline \multirow[b]{2}{*}{ GOAL-SUBJECT BUILDINGS } & \multicolumn{2}{|c|}{ Native Units } & \multirow{2}{*}{ Billion BTU } & \multirow{2}{*}{ Cost (in 2018\$) } \\
\hline & Quantity & Units & & \\
\hline Electricity & $27,063,119.5$ & Mwh & $92,339.4$ & $2,283,641,505.5$ \\
\hline Fuel Oil & $96,877.2$ & Thou. Gallons & $13,370.7$ & $233,882,141.5$ \\
\hline Natural Gas & $67,908,099.4$ & Thou. Cu. Ft. & $69,673.7$ & $430,165,087.5$ \\
\hline Lpg Propane & $9,919.6$ & Thou. Gallons & 912.6 & $14,408,118.1$ \\
\hline Coal & $287,129.1$ & Short Tons & $6,218.9$ & $30,425,300.3$ \\
\hline Purch Steam & $4,253.6$ & BBTU & $4,253.6$ & $107,141,786.9$ \\
\hline Purchased Renewable Energy & $1,477.0$ & BBTU & $1,477.0$ & $24,689,765.5$ \\
\hline $\begin{array}{l}\text { On-Site Renewables And } \\
\text { Adjustments }\end{array}$ & $4,409.1$ & BBTU & $4,409.1$ & $43,326,224.5$ \\
\hline Other & 479.2 & BBTU & 479.2 & $4,999,900.0$ \\
\hline End-Use Sector Total & & & $193,134.2$ & $3,172,679,829.8$ \\
\hline Gross Square Feet & $1,881,714.5$ & Thou. GSF & & \\
\hline GOAL-EXCLUDED FACILITIES & $\underline{\text { Nativ }}$ & Units & Billion BTU & Cost (in 2018\$) \\
\hline Electricity & $2,421,946.6$ & Mwh & $8,263.7$ & $215,190,677.0$ \\
\hline Fuel Oil & $1,080.7$ & Thou. Gallons & 149.1 & $2,007,792.0$ \\
\hline
\end{tabular}

129 See Ulrike Burkhardt and Bernd Kärcher, "Global Radiative Forcing from Contrail Cirrus," Nature Climate Change, March 2011, pp. 54-58 and Ulrike Burkhardt, Lisa Bock, and Andreas Bier, "Mitigating the Contrail Cirrus Climate Impact by Reducing Aircraft Soot Number Emissions," Climate and Atmospheric Science, October 2018, https://www.nature.com/articles/s41612-018-0046-4.

${ }^{130}$ Source: Department of Energy, "Comprehensive Annual Energy Data and Sustainability Performance," by Federal Agency, https://ctsedwweb.ee.doe.gov/Annual/Report/SiteDeliveredEnergyUseandCostsbyEndUseSectorAndEnergy TypeByFederalAgencyNativeUnitsAndBillionBtu.aspx; https://ctsedwweb.ee.doe.gov/Annual/Report/BEAReport.aspx?ef=Excel\&fy=1\&yo=\&ag=6\&au=false. 


\begin{tabular}{|c|c|c|c|c|}
\hline Natural Gas & $679,505.2$ & Thou. Cu. Ft. & 697.2 & $2,888,397.0$ \\
\hline Lpg Propane & 0.0 & Thou. Gallons & 0.0 & 0.0 \\
\hline Coal & 0.0 & Short Tons & 0.0 & 0.0 \\
\hline Purch Steam & 98.1 & BBTU & 98.1 & $4,296,646.0$ \\
\hline Purchased Renewable Energy & 0.0 & BBTU & 0.0 & 0.0 \\
\hline $\begin{array}{l}\text { On-Site Renewables And } \\
\text { Adjustments }\end{array}$ & 489.6 & BBTU & 489.6 & 0.0 \\
\hline Other & 0.0 & BBTU & 0.0 & 0.0 \\
\hline End-Use Sector Total & & & $9,697.7$ & $224,383,512.0$ \\
\hline Gross Square Feet & $11,718.9$ & Thou. GSF & & \\
\hline VEHICLES AND EQUIPMENT & \multicolumn{2}{|c|}{$\underline{\text { Native Units }}$} & Billion BTU & Cost (in 2018\$) \\
\hline Auto Gas & $90,608.4$ & Thou. Gallons & $11,326.0$ & $294,726,817.1$ \\
\hline Dist-Diesel & $711,014.5$ & Thou. Gallons & $98,182.2$ & $1,731,009,006.2$ \\
\hline Lpg Propane & 5.4 & Thou. Gallons & 0.5 & $12,287.0$ \\
\hline Aviation Gas & 433.2 & Thou. Gallons & 52.0 & $2,804,586.9$ \\
\hline Jet Fuel & $2,792,639.2$ & Thou. Gallons & $377,006.3$ & $7,149,029,327.8$ \\
\hline Navy Special & 0.0 & Thou. Gallons & 0.0 & 0.0 \\
\hline Other & $1,216.2$ & BBTU & $1,216.2$ & $31,895,107.8$ \\
\hline End-Use Sector Total & & & $487,783.2$ & $9,209,477,132.7$ \\
\hline $\begin{array}{l}\text { DEPARTMENT OF DEFENSE } \\
\text { TOTAL (FY 2018) }\end{array}$ & & & $690,615.1$ & $12,606,540,474.5$ \\
\hline
\end{tabular}

Figure 17 illustrates the DOD total facility energy use in Billions of British Thermal Units from electricity and purchased steam. Note that, while the facilities total energy production declined from FY1975 to FY2018, the proportion of electricity and steam generation, source unspecified, increased. In FY1975, electricity accounted for 20 percent of facilities energy use; by FY2018, electricity accounted for nearly 50 percent of facilities energy use.

Figure 17. DOD Facility Energy Use FY1975 to FY2018: Total, Electricity, and Purchased Steam ${ }^{131}$

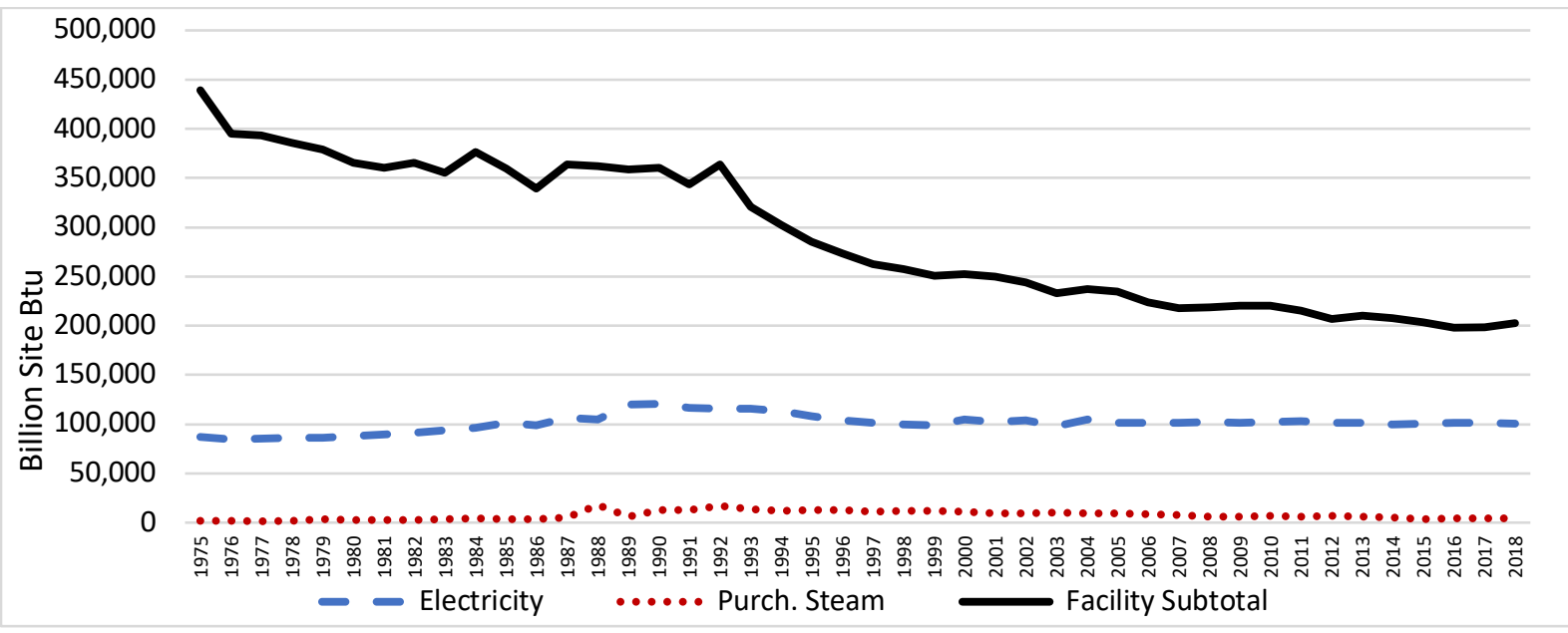

131 Source: Department of Energy data. 


\section{Appendix 2. Possible Next Steps for Congressional Action on the DOD and Climate Change}

By decreasing fuel use, the Pentagon has significantly reduced DOD greenhouse gas emissions in recent years. By continuing to decrease fossil fuel consumption, the US military would reduce overall US greenhouse gas emissions and could perhaps promote carbon sequestration (taking carbon out of the atmosphere and fixing it in the soil and trees).

There is room for the DOD to continue reductions, using many more modest measures including increasing fuel economy and using alternative fuels. More significant reductions in greenhouse gas emissions will be gained by restructuring, including making training more efficient, reducing US military operations and installations worldwide, and closing bases in the US. Some base closures and restructuring will be necessitated by climate change itself. Base closures could also lead to significant carbon sequestration if those public lands are reforested.

This is a win-win-win strategy. Reductions in fuel use saves money and makes the US military less vulnerable to fuel shortages; in the long run, reductions in fuel use and conversion of bases by reforestation decrease climate change caused impacts including insecurity; and conversion to renewable energy sources and alternative fuels could significantly boost the renewable energy industry and electric car industry in the US.

Congress might become much more active in tracking and reducing greenhouse gas emissions by the DOD. Specifically, Congress might require the Pentagon to supply more information on fuel consumption and energy use and require the Pentagon to increase its analysis and planning for a transition to reductions in fossil fuel use and to immediately reduce fuel consumption. Some potential actions are outlined below.

\section{Comprehensive reporting of DOD fuel consumption and energy usage.}

a. In all future years, the DOD should report fuel consumption to Congress in its budgetary submission and in a separate annual report on DOD fuel consumption. Consumption reports should be both aggregated and disaggregated (by fuel type, e.g. jet, diesel, and other fuels) each year by named operation and war, and for other operations and installations, for each operational command and each service. Consumption information should also be added to the annual Defense Logistics Agency Energy Fact books.

b. The DOD should report these same figures for the period from FY2000 through FY2019 in a separate report.

c. The DOD should report fuel consumption for training missions and public displays such as fly-over events. 


\section{Comprehensive analysis and planning}

a. DARPA should work with the services to produce a study showing current DOD non-tactical vehicle fleet fuel consumption, and to identify ways to immediately reduce fuel consumption beyond levels already targeted.

b. Each service should identify ways to reduce consumption of fuel by decreasing the fuel use and increasing the fuel efficiency of training exercises.

c. Each installation should inventory its environment to identify "heat islands" by the end of FY2020.

d. Each installation should produce plans to reduce overall energy consumption by 10 percent and 20 percent by the start of FY2022.

e. Identify installations that should be closed or reduced in size due to climate change impacts (such as rising sea levels or extreme weather). Develop a plan for converting these installations to sites for carbon sequestration.

\section{Comprehensive approach to reductions in fossil fuel usage.}

a. Switching to alternative fuels for electricity generation at all US military installations so that all DOD installations are 90 percent reliant on renewable technologies, e.g. wind, solar, geothermal, hydropower, and large storage capacity batteries, through power purchase agreements or local generation by 2022 .

b. Increase the rate of adoption of all electric, hybrid and plug in hybrid non-tactical fleet vehicles (NTV) based on the results of the DARPA study identified above. Move to 90 percent electric, or gas-electric hybrid, by 2022. Prioritize for new purchases the most efficient vehicles made in the US that meet the Department of Energy NTV fuel economy standards.

c. To reduce the "heat island" effect of large expanses of concrete and asphalt and thereby reduce the necessity for air conditioning on bases and other installations, each base shall inventory its percentage of tree cover and plant shade trees so that the percentage of shade tree coverage is increased by 10-20 percent by the end of FY2021.

\section{Military and installation base conversions and closures}

a. Designate which military and national guard bases and installations should be closed due to climate change impacts and which bases can be closed for other reasons, such as diminished threat. ${ }^{132}$ For example, Offutt Air Force Base in Nebraska, which suffered flooding in March 2019, and Tyndall Air Force Base, which was damaged by Hurricane Michael in October 2018, are to receive more than $\$ 1$ billion in funding for repairs contingent on producing a plan that includes "an explanation of how each military construction project will incorporate mitigation

\footnotetext{
132 Department of Defense, "Report on the Effects of a Changing Climate to the Department of Defense," Office of the Undersecretary of Defense for Acquisition and Sustainment, January 2019, https://climateandsecurity.files.wordpress.com/2019/01/sec 335 ndaareport effects of a changing climate to dod.pdf.
} 
measures that reduce the threat from extreme weather events, mean sea level fluctuation, flooding, and any other known environmental threat to resilience."133 Tyndall Air Force Base, which is extremely vulnerable to future hurricanes, might instead be closed, saving $\$ 300,000,000$ in construction.

b. As bases and installations are cleared of toxic contamination (such as chemical waste and asbestos), change land use so that carbon sequestration is possible, such as by planting trees or restoring wetlands. ${ }^{134}$

c. Use closed DOD bases and installations as sites of alternative energy productionwind, solar, or geothermal, as is most appropriate and efficient for that base or installation. Similarly, converted National Guard bases could become sites of alternative energy production and carbon sequestration.

${ }^{133}$ National Defense Authorization Bill, FY2020, House Bill, https://www.congress.gov/bill/116th-congress/housebill/2500/text.

${ }^{134}$ The EPA lists more than 130 clean-up sites that it cleaned up in the several rounds of Base Realignment and Closure. See EPA "Base Realignment and Closure (BRAC) Sites by State," https:/www.epa.gov/fedfac/baserealignment-and-closure-brac-sites-state. 